\title{
Human C3 mutation reveals a mechanism of dense deposit disease pathogenesis and provides insights into complement activation and regulation
}

\author{
Rubén Martínez-Barricarte, ${ }^{1}$ Meike Heurich, ${ }^{2}$ Francisco Valdes-Cañedo, ${ }^{3}$ \\ Eduardo Vazquez-Martul, ${ }^{3}$ Eva Torreira, ${ }^{1}$ Tamara Montes, ${ }^{1}$ Agustín Tortajada, ${ }^{1}$ \\ Sheila Pinto, ${ }^{1}$ Margarita Lopez-Trascasa, ${ }^{4}$ B. Paul Morgan, ${ }^{2}$ Oscar Llorca, ${ }^{1}$ \\ Claire L. Harris, ${ }^{2}$ and Santiago Rodríguez de Córdoba ${ }^{1}$
}

${ }^{1}$ Centro de Investigaciones Biológicas (CIB), Consejo Superior de Investigaciones Científicas, Centro de Investigación Biomédica en Enfermedades Raras and Instituto Reina Sofía de Investigaciones Nefrológicas, Madrid, Spain. ${ }^{2}$ Department of Infection, Immunity, and Biochemistry, School of Medicine, Cardiff University, Cardiff, United Kingdom. ${ }^{3}$ Servicios de Nefrología y Anatomía Patológica, Hospital Juan Canalejo, A Coruña, Spain. ${ }^{4}$ Unidad de Inmunología, Hospital Universitario de La Paz, Madrid, Spain.

\begin{abstract}
Dense deposit disease (DDD) is a severe renal disease characterized by accumulation of electron-dense material in the mesangium and glomerular basement membrane. Previously, DDD has been associated with deficiency of factor $\mathrm{H}(\mathrm{fH})$, a plasma regulator of the alternative pathway (AP) of complement activation, and studies in animal models have linked pathogenesis to the massive complement factor 3 (C3) activation caused by this deficiency. Here, we identified a unique DDD pedigree that associates disease with a mutation in the C3 gene. Mutant C ${ }_{923 \Delta \mathrm{DG}}$, which lacks 2 amino acids, could not be cleaved to C3b by the AP C3-convertase and was therefore the predominant circulating $\mathrm{C} 3$ protein in the patients. However, upon activation to $\mathrm{C} 3 \mathrm{~b}$ by proteases, or to $\mathrm{C} 3\left(\mathrm{H}_{2} \mathrm{O}\right)$ by spontaneous thioester hydrolysis, $\mathrm{C}_{923 \Delta \mathrm{DG}}$ generated an active AP C3-convertase that was regulated normally by decay accelerating factor (DAF) but was resistant to decay by fH. Moreover, activated $\mathrm{C}_{3} \mathrm{~b}_{923 \Delta \mathrm{DG}}$ and $\mathrm{C} 3\left(\mathrm{H}_{2} \mathrm{O}\right)_{923 \Delta \mathrm{DG}}$ were resistant to proteolysis by factor $\mathrm{I}(\mathrm{fI})$ in the presence of $\mathrm{fH}$, but were efficiently inactivated in the presence of membrane cofactor protein (MCP). These characteristics cause a fluid phase-restricted AP dysregulation in the patients that continuously activated and consumed C3 produced by the normal C3 allele. These findings expose structural requirements in $\mathrm{C} 3$ that are critical for recognition of the substrate $\mathrm{C} 3$ by the AP C3-convertase and for the regulatory activities of $\mathrm{fH}, \mathrm{DAF}$, and MCP, all of which have implications for therapeutic developments.
\end{abstract}

\section{Introduction}

Complement is a major component of innate immunity, with crucial roles in microbial killing, apoptotic cell clearance, immune complex handling, and modulation of adaptive immune responses. Complement is activated by 3 independent activation pathways: the classical pathway $(\mathrm{CP})$, the lectin pathway (LP), and the alternative pathway (AP). The critical steps in complement activation are the formation of unstable protease complexes, named complement factor 3-convertases (C3-convertases; specifically, $\mathrm{C} 3 \mathrm{bBb}$ for $\mathrm{AP}$ and $\mathrm{C} 4 \mathrm{~b} 2 \mathrm{a}$ for $\mathrm{CP}$ and $\mathrm{LP}$ ), and the cleavage of $\mathrm{C} 3$ by the convertases to generate $\mathrm{C} 3 \mathrm{~b}$. Convertase-generated $\mathrm{C} 3 \mathrm{~b}$ can form more AP C3-convertase, providing exponential amplification to the initial activation. Binding of $\mathrm{C} 3 \mathrm{~b}$ to the $\mathrm{C} 3$-convertases generates the $\mathrm{C} 5$-convertases with the capacity to bind and cleave $\mathrm{C5}$, initiating formation of the lytic membrane attack complex (MAC). In contrast to the CP and the LP, whose activation is triggered by immune complexes and bacterial mannose groups, respectively, the AP is intrinsically activated. Spontaneous activation of $\mathrm{C} 3$ in plasma occurs through the tick-over mecha-

Authorship note: Rubén Martínez-Barricarte and Meike Heurich, as well as Claire L. Harris and Santiago Rodríguez de Córdoba, contributed equally to this work. Conflict of interest: The authors have declared that no conflict of interest exists. Citation for this article: J Clin Invest. 2010;120(10):3702-3712. doi:10.1172/JCI43343. nism, which is initiated by hydrolysis of the internal C3 thioester to generate a C3b-like molecule, called $\mathrm{C} 3 \mathrm{i}$ or $\mathrm{C} 3\left(\mathrm{H}_{2} \mathrm{O}\right)$. Activation of $\mathrm{C} 3$ also occurs by the continuous low rate cleavage of $\mathrm{C} 3$ to $\mathrm{C} 3 \mathrm{~b}$ by plasma proteases (1). Progression of complement activation results from the balance between the rate at which the initial activation is amplified and the rate at which C3b and the AP C3-convertases are inactivated. Foreign substances on microbial pathogens (AP), antibodies (CP), or mannan (LP) disturb the balance in favor of amplification, causing target opsonization, leukocyte recruitment, inflammation, and cell lysis. In health, activation of C3 in plasma is kept at a very low level, and deposition of C3b and further activation of complement is limited to the surface of pathogens by multiple regulatory proteins, including factor $\mathrm{H}$ (fH), C4b-binding protein (C4BP), membrane cofactor protein (MCP), decay accelerating factor (DAF), complement receptor 1 (CR1), and CD59. These control complement activation and avoid wasteful consumption of components by inactivating $\mathrm{C} 3 \mathrm{~b}$ or $\mathrm{C} 4 \mathrm{~b}$, by dissociating the $\mathrm{C} 3 / \mathrm{C} 5$-convertases, or by inhibiting membrane attack complex (MAC) formation (2-4).

Dense deposit disease (DDD) is a rare form of glomerulonephritis that affects children and young adults and frequently develops into end-stage renal disease (ESRD; ref. 5). It is characterized by proliferation of mesangial and endothelial cells and by thickening of the peripheral capillary walls in the glomeruli (due to subendo- 
Table 1

Progression of DDD patients

\begin{tabular}{|c|c|c|c|c|c|c|c|c|c|c|c|}
\hline Patient & $\begin{array}{l}\text { Age } \\
\text { (yr) }\end{array}$ & Sex & Age & $\begin{array}{l}\text { First cl } \\
\mathrm{Cr}\end{array}$ & $\begin{array}{l}\text { inic visit } \\
\text { Proteinuria }\end{array}$ & Microhematuria & $\begin{array}{l}\text { Current kidney } \\
\text { status }\end{array}$ & $\begin{array}{c}\text { Time to } \\
\text { ESRD }\end{array}$ & Biopsy & $\begin{array}{c}\text { Renal } \\
\text { transplant }\end{array}$ & $\begin{array}{c}\text { Graft } \\
\text { recurrence }\end{array}$ \\
\hline GN28 & 53 & Female & $28 \mathrm{yr}$ & $0.9 \mathrm{mg} / \mathrm{dl}$ & $1.5 \mathrm{~g} / 24 \mathrm{~h}$ & Yes & ESRD & $7 \mathrm{yr}$ & Yes & 3 & Yes $^{A}$ \\
\hline III-1 & 26 & Male & $23 \mathrm{yr}$ & $1.4 \mathrm{mg} / \mathrm{dl}$ & $0.4 \mathrm{~g} / 24 \mathrm{~h}$ & Yes & Functioning ${ }^{B}$ & - & Yes & No & - \\
\hline III-2 & 26 & Male & $16 \mathrm{yr}$ & $1.6 \mathrm{mg} / \mathrm{dl}$ & $0.6 \mathrm{~g} / 24 \mathrm{~h}$ & Yes & ESRDC & $9 \mathrm{yr}$ & Yes & No & - \\
\hline
\end{tabular}

ATwo recurrences, and current transplant indicative of early stages of disease. BEarly stages of disease: persistent microscopic hematuria, 96 ml/min glomerular filtration rate. CPeritoneal dialysis.

thelial and intramembranous dense deposits) that present a double-contour appearance upon light microscopy. The morphological hallmark of DDD is the presence of dense deposits within the glomerular basement membrane (GBM), as resolved by EM (6). The chemical composition of the dense deposits is largely unknown. Notably, IgG is absent from them and from other regions of the glomerulus, which excludes a role for immune complexes in their formation. DDD is associated with complement abnormalities that lead to intense deposition of C3 activation products in GBM and persistent reduction of $\mathrm{C} 3$ serum levels. Among the different factors associated with these complement abnormalities are the deficiency of the plasma AP regulator $\mathrm{fH}$, as a result of mutations in the $\mathrm{CFH}$ gene or the presence of autoantibodies against $\mathrm{fH}$, or the presence of autoantibodies against the $\mathrm{C} 3$-convertase (C3 nephritic factors; C3Nef). Familial cases of DDD are exceptional. There are only approximately 6 patients described in the literature in which deficiency of $\mathrm{fH}$, either heterozygous or homozygous, is associated with the development of DDD. In all but one of these cases, the $\mathrm{fH}$ deficiency is caused by mutations in $\mathrm{CFH}$ that result in truncations or amino acid substitutions that impair secretion of $\mathrm{fH}$ into circulation (7-9). The exception is the case of a CFH mutation in the complement regulatory region of $\mathrm{fH}$ that markedly reduced both the fI-mediated C3b cofactor activity and the AP C3-convertase decayaccelerating activity of $\mathrm{fH}(10)$.

The severe dysregulation of the AP observed in DDD patients is consistent with data from animals presenting this renal phenotype. In the pig, $\mathrm{fH}$ deficiency results in a progressive glomerulonephritis, similar to human DDD, which leads to renal failure (11). Similarly, $\mathrm{fH}-\mathrm{knockout}$ mice spontaneously develop a glomerulonephritis that
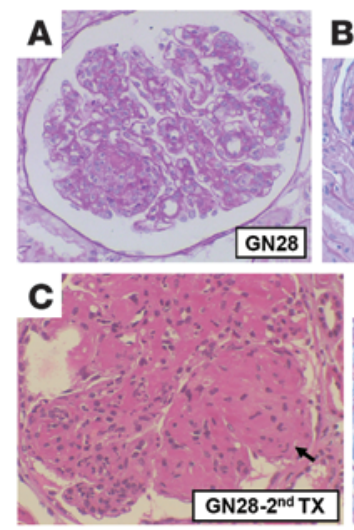

\section{Figure 1}
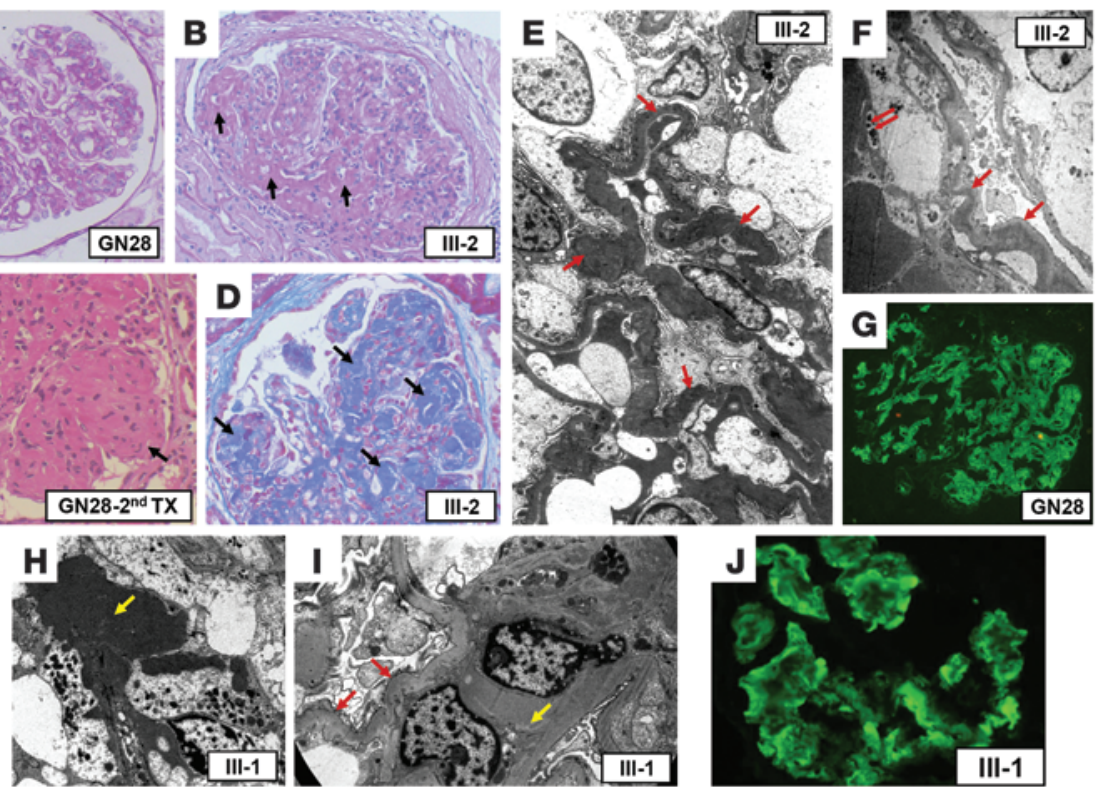

Histology, immunofluorescence, and EM findings. The first kidney biopsy in GN28 was performed in 1985. Although there was considerable variation in glomerular changes, there was remarkable similarity in the light, immunofluorescence, and ultrastructural findings in the original kidney biopsy and 2 allograft biopsies of GN28 and the kidney biopsies from III-1 and III-2. The characteristic histological lesion consisted of segmental mesangial hypercellularity with thickened, eosinophil-rich segments of basement membrane (A and B, arrows). The affected glomerular segments were PAS positive and reacted to trichrome stain (D, arrow). The affected tufts showed hypercellularity, leukocyte infiltration, and endothelial swelling. The mesangium showed variable expansion, matrix accumulation, and a lobular pattern ( $\mathbf{C}$ and $\mathbf{D}$, arrows). The main immunofluorescence findings were prominent and diffuse $\mathbf{C} 3$ deposits, granular and nodular in some glomerular areas (G and $\mathbf{J})$. Mild deposits of $\mathbf{C} 1 \mathrm{q}, \operatorname{IgA}$, and $\lg M$ were also associated with these deposits (not shown). All biopsies showed similar ultrastructural alterations consisting of a ribbon-like, osmiophilic deposit present in the GBM (E and I, red arrows). These deposits occasionally showed signs of dissolution with translucent areas ( $\mathbf{F}$, red arrows). The mesangial areas showed increased mesangial matrix with electron-dense deposits ( $\mathbf{H}$ and $\mathbf{I}$, yellow arrows). Original magnification: $\times 400$ (A, B, G, and J); $\times 500$ (C and D); $\times 2,200(\mathbf{E}$ and F); $\times 5,500$ (H); $\times 7,800$ (I). Patient number is indicated within each panel. 
Table 2

Complement data in DDD patients and relatives

$\begin{array}{lccccccc}\text { Patient } & \text { Relation } & \text { C3 } & \text { C4 } & \text { fH } & \text { fl } & \text { fB antigenic } & \text { fB hemolytic } \\ \text { GN28 } & \text { Index case } & \mathbf{9 4 . 2} & 26 & 21 & 100 \% & \mathbf{6 . 3} & \mathbf{3 0 \%} \\ \text { I-1 } & \text { Father } & 179 & 36 & 36 & 100 \% & 25 & 100 \% \\ \text { III-1 } & \text { Son } & \mathbf{9 4 . 4} & 22 & 22 & 100 \% & \mathbf{1 0} & \mathbf{1 8 \%} \\ \text { III-2 } & \text { Son } & \mathbf{8 0 . 5} & 18 & 32 & >100 \% & \mathbf{5 . 5} & \mathbf{2 7 \%} \\ \text { II-3 } & \text { Sister } & 114 & 26 & 43 & >100 \% & 34.6 & 100 \% \\ \text { II-4 } & \text { Brother } & 111 & 16 & 28 & >100 \% & 27 & 100 \%\end{array}$

Values are shown as $\mathrm{mg} / \mathrm{dl}$ with the exception of $\mathrm{fl}$ and $\mathrm{fB}$ hemolytic, which are shown as percent of control. Reference ranges are as follows: $\mathrm{C} 3,80-177 \mathrm{mg} / \mathrm{dl} ; \mathrm{C} 4,14-47$ $\mathrm{mg} / \mathrm{dl} ; \mathrm{fH}, 10-35 \mathrm{mg} / \mathrm{dl} ; \mathrm{fB}$ antigenic, $7.5-28 \mathrm{mg} / \mathrm{dl}$. C3 and fB values for the 3 individuals carrying the $C 3$ mutation c.2767_2774delACGGTG (p.923 $\triangle D G$ ) are shown in bold; sequencing of the $C F H, C F B, C F I$, and $M C P$ genes did not identify additional mutations in these individuals.

(13) and that the lytic pathway is not involved in the pathogenesis (14). Because $\mathrm{fH}$ regulates complement both in circulation and on cell surfaces, it is still debatable whether cell surface dysregulation plays a relevant role in DDD pathogenesis.

Here we report the first case to our knowledge of DDD caused by a mutation in the $C 3$ gene, the functional characterization of which provided unique insights into DDD pathogenesis. Our findings provided conclusive evidence in humans that fluid phase-restricted AP dysregulation, which caused continuous generation of $\mathrm{C} 3 \mathrm{~b}$ in plasma, plays a major role in DDD pathogenesis. Furthermore, analysis of this C3 mutation advanced our understanding of the activation and regulation of the AP C3-convertase, providing useful information to unravel the structural requirements underlying the substrate recognition and regulatory activities of $\mathrm{fH}, \mathrm{DAF}$, and MCP.

\section{Results}

Familial case of DDD. We present the case of a 53-year-old woman (patient GN28; II-2) and her 26-year-old identical twin sons (referred to herein as III-1 and III-2). Their clinical presentation and development of disease are described in detail in Methods and summarized in Table 1. Biopsies taken from GN28, III-1, and III-2 illustrated similar findings by light and immunofluorescent microscopy that were consistent with a diagnosis of membranoproliferative glomerulonephritis (Figure 1). GN28 and III-2 reached ESRD after a prolonged period of progressive deterioration. III-1 showed persistent microhematuria and limited proteinuria, but still preserved renal function. Nevertheless, the profound pathological alterations found in the kidney biopsy from III-1 suggests that the patient will follow the same course to ESRD as his affected relatives. GN28 has been transplanted 3 times, with the disease recurring in all 3 allografts following the same course of disease as the original kidney.

Definitive diagnosis of DDD in GN28, III-2, and III-1 was established on the basis of EM analyses in renal biopsies performed at early stages of the disease. These analyses illustrated an electrondense ribbon-like accumulation along the GBM and local electrondense deposits in the mesangium. The latter was the predominant lesion found in the kidney biopsy of III-1. This finding may explain why III-1 still preserves renal function and suggest that, as disease progresses, increasing electron-dense deposits will be found in the GBM in this patient. The findings by EM matched the histology and immunofluorescence results (Figure 1) and were also consis- tent with the observations in biopsies from 2 allografts received by GN28 in which disease recurred.

Complement analysis in the 3 DDD-affected patients illustrated decreased levels of both C3 and $\mathrm{fB}$ (low-normal range) compared with their healthy relatives (Table 2), suggestive of activation through the AP. No activated C3 fragments were detected in plasma by Western blot, but terminal complement complex (TCC) levels were slightly elevated in GN28 and III-1 compared with controls (2.4 and $1.8 \mu \mathrm{g} / \mathrm{ml}$, respectively; upper limit of normal, $1.24 \mu \mathrm{g} / \mathrm{ml}$ ), indicating persistent low-grade C3 activation. Notably, although decreased, C3 levels in these patients were substantially higher than those usually found in DDD patients. Assays to identify $\mathrm{C} 3 \mathrm{Nef}$ or anti-fH autoantibodies were negative. Levels of MCP on the surface of peripheral blood lymphocytes were normal in all 3 DDD patients.

Genetic analyses identify a C3 mutation associated with DDD. GN28, III-1, and III-2 were found to carry a mutation in heterozygosis in the C3 gene (Figure 2). The mutation, c.2767_2774delACGGTG (C3 $\left.{ }_{923 \Delta D G}\right)$ in exon 21 , results in a mutated protein $\left(\mathrm{C}_{923 \Delta \mathrm{DG}}\right)$ lacking 2 amino acids (Asp923 and Gly924) in the MG7 domain of C3. No mutations were found in any other screened gene, including $C F H, M C P$, $C F I$, and $C F B$, and the $C 3_{923 \triangle D G}$ mutation was not detected in more that 300 unrelated individuals. In our pedigree, $C 3_{923 \Delta D G}$ was exclusively present in all 3 DDD-affected members (Figure 2). It was asso-

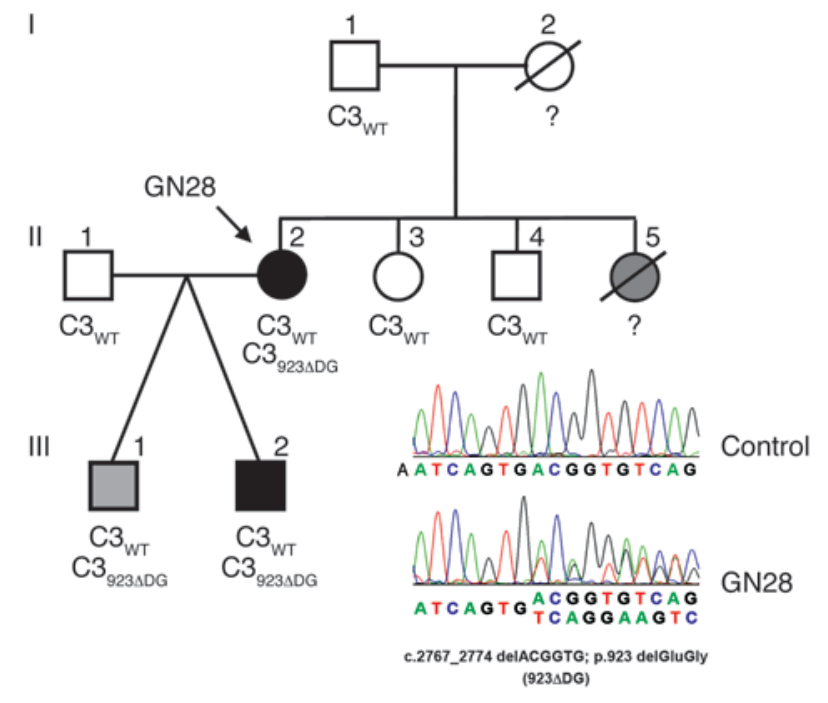

\section{Figure 2}

Mutation in the $\mathrm{C} 3$ gene in a multiaffected DDD pedigree. Pedigree of index case GN28 is illustrated. Individuals are identified by numbers within each generation. Affected individuals are indicated by black symbols. The twin brother III-1 (gray symbol) has not developed ESRD, but shows early signs of disease. II-5 is a sister of GN28 whose death at 13 years of age was attributed to glomerulonephritis. C3 alleles carried by the individuals are shown. The chromatogram corresponding to the DNA sequence surrounding the mutated nucleotides in $C 3$ is shown for GN28 and a control sample. The corresponding amino acid sequences for the WT and mutated alleles are indicated. Amino acid numbering refers to the translation start site $(M e t+1)$, and the nucleotide nomenclature refers to nucleotide A in the ATG translation initiation codon, according to Human Genome Variation Society recommendations for description of sequence variants. 

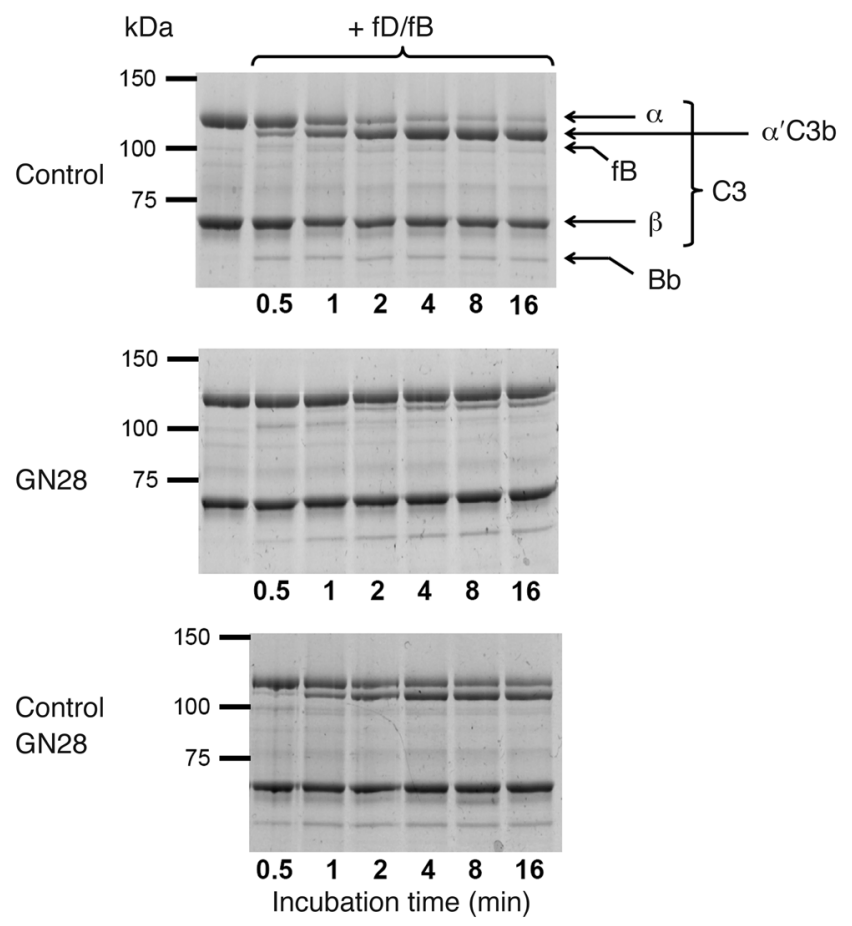

ciated with decreased C3 levels, probably secondary to C3 consumption, as the mutation also associated with low fB levels (Table 2). This evidence of complement activation and the observation that C3 ${ }_{923 \Delta \mathrm{DG}}$ was expressed normally in cells transfected with an expression plasmid in vitro (Supplemental Figure 1; supplemental material available online with this article; doi:10.1172/JCI43343DS1) suggest that $C 3_{923 \triangle D G}$ is likely a gain-of-function mutation causing constitutive activation of complement. C3 mutation screening in all DDD patients in our cohort $(n=8)$ failed to identify additional patients carrying the $C 3_{923 \triangle D G}$ mutation or additional C3 mutations.

The $C 3_{923 \triangle D G}$ mutation deletes 2 amino acids within MG7 in the polypeptide linking the MG7 and CUB domains. The deletion shortens the distance between the MG7 and CUB domains, likely displacing the upstream and downstream amino acids from their original positions. It is likely that these structural changes alter the function of $\mathrm{C} 3$ in a way that results in DDD. To test this possibility, we purified the mutant $\mathrm{C}_{923 \Delta \mathrm{DG}}$ protein and assessed its function.

C $3_{923 \triangle D G}$ is the major circulating C3 protein in the DDD patients. C3 was purified to homogeneity from EDTA-plasma obtained from GN28, III-1, III-2, and normal controls (Supplemental Methods and Supplemental Figure 2). Interestingly, when mixed with $\mathrm{fB}$ and $\mathrm{fD}$ in the presence of $\mathrm{Mg}^{2+}$, the C3 purified from GN28, III-1, and III-2 was largely resistant to $\mathrm{C} 3 \mathrm{~b}$ generation (Figure 3 ). The presence of potential inhibitory contaminants in the $\mathrm{C} 3$ preparations from GN28, III-1, and III-2 was ruled out by showing that in a C3 preparation containing equal amounts of normal control $\mathrm{C} 3$ and mutant C3 purified from GN28, approximately half the C3 was cleaved, corresponding to the amount of normal protein present (Figure 3).

Separation of $\mathrm{C}_{923 \Delta \mathrm{DG}}$ from $\mathrm{C} 3_{\mathrm{WT}}$ in the $\mathrm{C} 3$ preparation from GN28, III-1, and III-2 was achieved using a Mono S HR 1.6/5 cation exchange column (GE Healthcare) with a pH 6-8 gradient $(20 \mathrm{mM}$ $\mathrm{Na} / \mathrm{K}$ phosphate, $40 \mathrm{mM} \mathrm{NaCl}$ ). In this chromatographic setting, C3 from GN28 produced 2 well-separated peaks, the first comigrating with the single $\mathrm{C} 3$ peak obtained from a similar experiment

\section{Figure 3}

Total C3 from GN28 is only partially cleaved to C3b in the presence of $\mathrm{fB}$ and fD. Coomassie-stained gels correspond to the SDS-PAGE analyses of $\mathrm{C} 3$ purified from GN28 and a normal control after incubation with fB and $f D$. The experiment was repeated twice with identical results. Top: C3 purified from normal individuals was rapidly and completely activated to $\mathrm{C} 3 \mathrm{~b}$ (determined by cleavage of the C3 $\alpha$ chain) in the presence of $f B$ and $f D$. This activation correlated with consumption of $f B$ and the appearance of the $\mathrm{Bb}$ fragment, indicating formation of the AP C3-convertase. Middle: Same experiment with C3 purified from GN28. Despite formation of the AP C3-convertase (demonstrated by consumption of $\mathrm{fB}$ and generation of the $\mathrm{Bb}$ fragment), only a small proportion of the C3 was activated to C3b. This suggests that C3 purified from the GN28 plasma contains 2 different C3 forms (WT and mutant protein), and that only $\mathrm{C}_{\mathrm{WT}}$ is cleaved to C3b. Bottom: To rule out the presence of inhibitors in the $\mathrm{C} 3$ preparation from the GN28 plasma, a mixing experiment (equivalent amounts of control and GN28 C3) showed that addition of $\mathrm{fB}$ and $f D$ caused activation of $50 \%$ of the $\mathrm{C} 3$, likely $\mathrm{C} 3_{\mathrm{WT}}$.

with a C3 preparation from a control individual (Figure 4A). Proteomic analysis of the $\mathrm{C} 3$ protein contained in each peak confirmed that the second peak corresponded to pure $\mathrm{C} 3_{923 \Delta \mathrm{DG}}$ mutant protein (Figure $4 \mathrm{~B}$ ). EM analyses of the $\mathrm{C} 3_{\mathrm{WT}}$ and $\mathrm{C} 3_{923 \Delta \mathrm{DG}}$ proteins purified from the GN28 plasma resulted in 3D structures that were indistinguishable at the resolution level of this technique (approximately $25 \AA$ ), which indicates that the deletion of the 2 amino acids in the $\mathrm{C} 3_{923 \Delta \mathrm{DG}}$ mutant did not cause gross changes in the structure of the $\mathrm{C} 3$ protein. The structures also demonstrated that $\mathrm{C}_{923 \Delta \mathrm{DG}}$ circulates in plasma mainly in the native (nonactivated) C3 conformation (Supplemental Figure 3). Similar proportions (approximately 1:2) of $\mathrm{C} 3_{\mathrm{WT}}$ and $\mathrm{C} 3_{923 \Delta \mathrm{DG}}$ were present in the plasma samples from the $3 \mathrm{C}_{923 \Delta \mathrm{DG}}$ mutation carriers (Table 3 ).

When purified $\mathrm{C} 3_{923 \Delta \mathrm{DG}}$ was incubated with $\mathrm{fB}$ and $\mathrm{fD}$ in the presence of $\mathrm{Mg}^{2+}$, no generation of $\mathrm{C} 3 \mathrm{~b}$ was observed despite cleavage of $\mathrm{fB}$ and generation of $\mathrm{Bb}$; conversely, $\mathrm{C} 3_{\mathrm{WT}}$ was completely converted to $\mathrm{C} 3 \mathrm{~b}$ under these conditions (Figure $5 \mathrm{~A}$ ). To confirm that C3 ${ }_{923}{ }_{\text {D G }}$ could not be activated to C3b by the AP C3-convertase, we performed surface plasmon resonance (SPR; Biacore) experiments with the $\mathrm{C} 3_{923 \Delta \mathrm{DG}}$ and $\mathrm{C} 3_{\mathrm{WT}}$ proteins purified from GN28 and healthy controls, respectively. We immobilized a small amount of $\mathrm{C} 3 \mathrm{~b}_{\mathrm{WT}}$ onto a Biacore chip and generated a nidus of convertase with $\mathrm{fB}$ and $\mathrm{fD}$. Then, either $\mathrm{C} 3_{\mathrm{WT}}$ or $\mathrm{C} 3_{923 \Delta \mathrm{DG}}$ was flowed over the surface as substrate of this convertase; activation of C $3_{\mathrm{WT}}$ or $\mathrm{C} 3_{923 \Delta \mathrm{DG}}$ exposes the thioester and results in accumulation of protein onto the Biacore chip via a covalent link. In agreement with previous experiments, when $\mathrm{C} 3_{923 \Delta \mathrm{DG}}$ was flowed, no protein deposited on the surface, in contrast to the deposition evident when $\mathrm{C} 33_{\mathrm{WT}}$ was flowed (Figure 5B), which indicated that the mutant $\mathrm{C}_{923 \Delta \mathrm{DG}}$ was not converted into nascent C3b by the AP C3-convertase. As a whole, these experiments demonstrated that $\mathrm{C} 3_{923 \Delta \mathrm{DG}}$ is the major $\mathrm{C} 3$ protein circulating in the plasma of the DDD patients, because the constitutive AP activation present in these individuals exclusively consumed the $\mathrm{C} 3_{\mathrm{WT}}$ produced by the normal $\mathrm{C} 3$ allele.

$\mathrm{C}_{923 \Delta D G}$ activates to $\mathrm{C} 3\left(\mathrm{H}_{2} \mathrm{O}\right)_{923 \Delta D G}$ and generates an active AP C3-convertase. We next sought to determine why $\mathrm{C} 3_{\text {WT }}$ produced by the normal allele was consumed in $\mathrm{C} 3_{923 \Delta \mathrm{DG}}$ carriers. $\mathrm{C} 3_{923 \Delta \mathrm{DG}}$ was not converted to $\mathrm{C} 3 \mathrm{~b}$ when mixed with $\mathrm{fB}$ and $\mathrm{fD}$ in the presence of $\mathrm{Mg}^{2+}$ (Figure 5A). However, in these experiments, $\mathrm{fB}$ was completely consumed to $\mathrm{Bb}$, which suggests that the preparations contain some hydrolyzed $\mathrm{C} 3_{923 \Delta \mathrm{DG}}$ that binds and activates $\mathrm{fB}$ and is therefore able to form an active AP C3-convertase. We have previously 

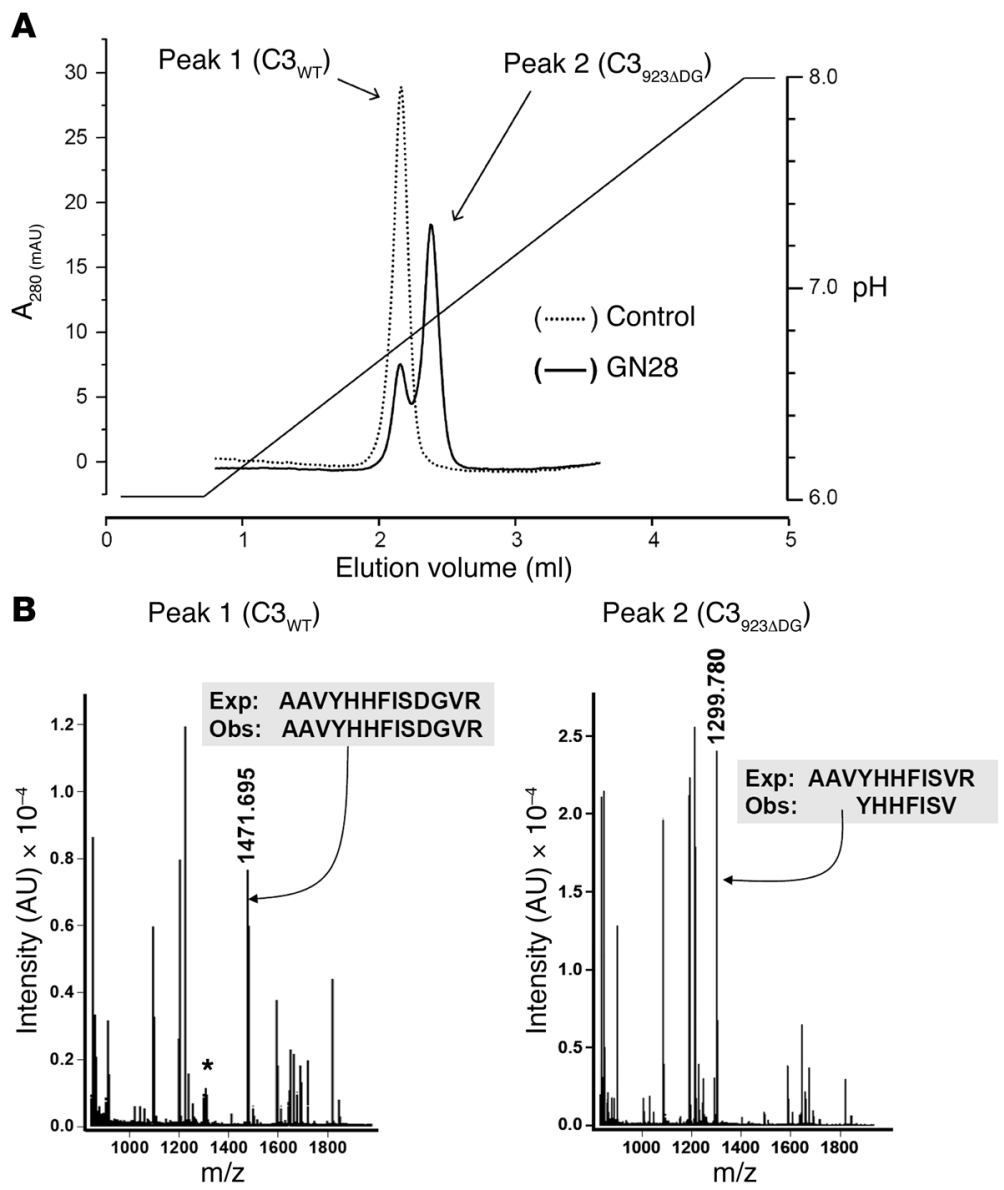

Figure 4

Purification of the mutant allele $\mathrm{C}_{923 \Delta \mathrm{DG}}$. (A) $\mathrm{C}_{923 \Delta \mathrm{DG}}$ and $\mathrm{C} 3_{\mathrm{WT}}$ were separated as described in Methods. The elution profiles of this chromatographic separation of C3 prepared from control plasma (dotted line) and from GN28 plasma (solid line) are indicated. (B) The identity of the C 3 variants was determined by mass spectrometry, as described in Methods. The minor C3wt peak showed some contamination of the major $\mathrm{C}_{923 \Delta \mathrm{DG}}$ mutant protein (asterisk). Exp, expected; Obs, observed. compared with $\mathrm{C} 3\left(\mathrm{H}_{2} \mathrm{O}\right)_{\mathrm{WT}}$ (Figure $\left.7 \mathrm{~A}\right)$. In complementary experiments, we found that this decreased binding impaired the capacity of $\mathrm{fH}$ to both decay the convertase generated from $\mathrm{C} 3\left(\mathrm{H}_{2} \mathrm{O}\right)_{923 \Delta \mathrm{DG}}($ Figure $7 \mathrm{~B})$ and act as a cofactor in the fl-mediated inactivation of $\mathrm{C} 3\left(\mathrm{H}_{2} \mathrm{O}\right)_{923 \Delta \mathrm{DG}}$ (Figure 7D). In contrast to the results obtained with $\mathrm{fH}$, the $\mathrm{C} 3$-convertase generated from $\mathrm{C} 3\left(\mathrm{H}_{2} \mathrm{O}\right)_{923 \Delta \mathrm{DG}}$ was efficiently decayed by DAF (Figure 7C).

$M C P$, but not $f H$, catalyzes fI cleavage of $C 3 b_{923 \Delta D G}$ and $\mathrm{C} 3\left(\mathrm{H}_{2} \mathrm{O}\right)_{923 \Delta \mathrm{DG}}$. We generated large amounts of $\mathrm{C} 3 \mathrm{~b}_{923 \Delta \mathrm{DG}}$ using trypsin and $\mathrm{C} 3\left(\mathrm{H}_{2} \mathrm{O}\right)_{923 \Delta \text { DG }}$ using $0.33 \mathrm{M}$ potassium isothiocyanate, and used them to test the cofactor activities of $\mathrm{fH}$ and MCP for fl-mediated proteolysis. In agreement with our findings described above, $\mathrm{C} 3\left(\mathrm{H}_{2} \mathrm{O}\right)_{923 \Delta \mathrm{DG}}$ interacted with and consumed $\mathrm{fB}$ in the presence of $\mathrm{fD}$ and $\mathrm{Mg}^{2+}$; trypsin-generated $\mathrm{C}_{3} \mathrm{~b}_{923 \Delta \mathrm{DG}}$ behaved similarly (Supplemental Figure 4). The trypsingenerated $\mathrm{C} 3 \mathrm{~b}_{923 \Delta \mathrm{DG}}$ also formed an active AP C3-convertase on a Biacore chip, although it showed less than $5 \%$ the activity of the AP C3-convertase generated with $\mathrm{C} \mathrm{b}_{\mathrm{WT}}$ (data not shown). Addition of C3 $\mathrm{b}_{923 \Delta \mathrm{DG}}$ to normal human sera activated complement and consumed C3 (Figure 8), which indicated that, despite its low activity, the mutant convertase was able to dysregulate the $\mathrm{AP}$, most likely because $\mathrm{C} 3 \mathrm{~b}_{923 \Delta \mathrm{DG}}$ is resistant to inactivation by $\mathrm{fl}$ and $\mathrm{fH}$. As expected, $\mathrm{C} 3 \mathrm{~b}_{\mathrm{WT}}$ had some capacity to activate $\mathrm{C} 3$ in normal serum, but this was much reduced compared with $\mathrm{C}_{3} \mathrm{~b}_{923 \Delta \mathrm{DG}}$.

In order to confirm the differences in cofactor activity of $\mathrm{fH}$ and MCP in the fI-mediated proteolysis of $\mathrm{C} \mathrm{b}_{923 \Delta \mathrm{DG}}$ and $\mathrm{C} 3\left(\mathrm{H}_{2} \mathrm{O}\right)_{923 \Delta \mathrm{DG}}$, we performed a fluid phase assay. Identical amounts of $\mathrm{C}_{3} \mathrm{~b}_{923 \Delta \mathrm{DG}}$ and $\mathrm{C} \mathrm{b}_{\mathrm{WT}}$ were added to purified $\mathrm{fH}$ (or MCP) in the presence of $\mathrm{fl}$ and incubated for 1, 2, 5, 10, 15, and 30 minutes at $37^{\circ} \mathrm{C}$. $\mathrm{C}_{3} \mathrm{~b}_{923 \Delta \mathrm{DG}}$ was resistant to inactivation by $\mathrm{fl}$ in the presence of $\mathrm{fH}$, but was inactivated by fl with soluble MCP (sMCP) at the same rate as C $3 b_{\text {WT }}$ (Figure 9). The same cofactor selectivity was found for $\mathrm{C} 3\left(\mathrm{H}_{2} \mathrm{O}\right)_{923 \Delta \text { DG }}$ (Figure 10). used SPR to monitor C3bBb formation and dissociation in real time (15). Hydrolyzed C $3_{\text {WT }}(1,224 \mathrm{RU})$ or C $3_{923 \Delta \mathrm{DG}}(1,067 \mathrm{RU})$ was thiol-coupled to a CM5 chip, and convertase formation was analyzed by flowing $\mathrm{fB}$ ( 270 to $17 \mathrm{nM}$ ) over the surface in the presence of $\mathrm{fD}(43 \mathrm{nM})$. Kinetics were analyzed according to the Langmuir $1: 1$ binding model, and convertase formation by $\mathrm{C} 3\left(\mathrm{H}_{2} \mathrm{O}\right)_{923 \Delta \mathrm{DG}}$ and $\mathrm{C} 3\left(\mathrm{H}_{2} \mathrm{O}\right)_{\text {wT }}$ was found to be comparable (Figure 6A). We tested next whether the AP C3-convertase generated from C3 $\left(\mathrm{H}_{2} \mathrm{O}\right)_{923 \Delta D G}$ was capable of activating $\mathrm{C}_{\text {WT. }}$. We generated a C3-convertase immobilized onto a Biacore chip using either $\mathrm{C} 3\left(\mathrm{H}_{2} \mathrm{O}\right)_{923 \Delta \mathrm{DG}}$ or $\mathrm{C} 3\left(\mathrm{H}_{2} \mathrm{O}\right)_{\mathrm{WT}}$ and flowed $\mathrm{C} 3_{\mathrm{WT}}$ over the surface. The mutant $\mathrm{C} 3$-convertase was able to activate $\mathrm{C} 3_{\mathrm{WT}}$, although it showed approximately $50 \%$ of the activity of the WT AP C3-convertase (Figure 6B).

$\mathrm{C} 3\left(\mathrm{H}_{2} \mathrm{O}\right)_{923 \Delta D G}$ generates a C3-convertase resistant to $\mathrm{fH}$ inactivation. We have shown here that $\mathrm{C}_{923 \Delta \mathrm{DG}}$ activated spontaneously and that the activated $\mathrm{C} 3\left(\mathrm{H}_{2} \mathrm{O}\right)_{923 \Delta \mathrm{DG}}$ interacted normally with $\mathrm{fB}$ to generate an active $\mathrm{C} 3$-convertase. To determine whether the mutant $\mathrm{C} 3$ convertase is regulated efficiently by $\mathrm{fH}$, we immobilized $\mathrm{C} 3\left(\mathrm{H}_{2} \mathrm{O}\right)_{\mathrm{WT}}$ or $\mathrm{C} 3\left(\mathrm{H}_{2} \mathrm{O}\right)_{923 \Delta \mathrm{DG}}$ as described above and flowed $\mathrm{fH}(1 \mu \mathrm{M}$ to $8 \mathrm{nM})$ over the surface. The affinity of $\mathrm{C} 3\left(\mathrm{H}_{2} \mathrm{O}\right)_{923 \Delta \mathrm{DG}}$ for $\mathrm{fH}$ was reduced

\section{Discussion}

Here we report the identification and functional characterization of $C 3_{923 \Delta D G}$, which we believe to be the first C3 mutation associated with DDD. The functional consequences of this mutation are remarkable, providing fundamental insights into both DDD pathogenesis and structural aspects of AP C3-convertase control

\section{Table 3}

C3 proteins in the plasma of $C 3_{923 \Delta D G}$ mutation carriers

\begin{tabular}{|c|c|c|c|}
\hline Patient & Allele & C3 (mg/dl) & Percent total C3 \\
\hline GN28 & $\mathrm{C} 3_{W T}$ & 26 & $27 \%$ \\
\hline GN28 & $\mathrm{C} 3_{923 \Delta \mathrm{DG}}$ & 68 & $73 \%$ \\
\hline|| $\mid-1$ & C3WT & 31 & $32 \%$ \\
\hline|| $\mid-1$ & $\mathrm{C} 3_{923 \Delta \mathrm{DG}}$ & 64 & $68 \%$ \\
\hline$|I|-2$ & C3WT & 28 & $35 \%$ \\
\hline$|I|-2$ & $\mathrm{C} 3_{923 \Delta \mathrm{DG}}$ & 52 & $65 \%$ \\
\hline
\end{tabular}

Total C3 levels were $94 \mathrm{mg} / \mathrm{dl}$ in GN28, $95 \mathrm{mg} / \mathrm{dl}$ in III-1, and $80 \mathrm{mg} / \mathrm{dl}$ in III-2. 

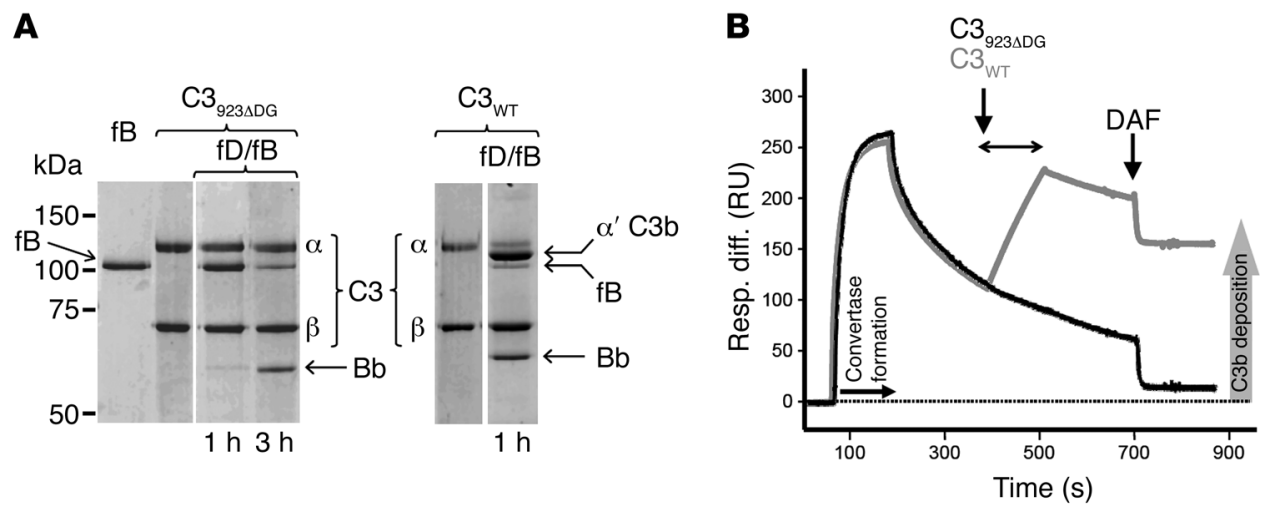

\section{Figure 5}

Resistance of purified $\mathrm{C}_{923 \Delta \mathrm{DG}}$ to cleavage by the AP C3-convertase. (A) C3 ${ }_{923 \Delta \mathrm{DG}}$ and C3WT were purified to homogeneity and tested for their capacity to be cleaved to $\mathrm{C} 3 \mathrm{~b}$ in the presence of $\mathrm{fB}$ and $\mathrm{fD}$; only the $\alpha$ chain of $\mathrm{C} 3_{\mathrm{wT}}$ was cleaved. Of note, $\mathrm{C} 3_{923 \Delta \mathrm{DG}}$ Consumed $\mathrm{fB}$, illustrating formation of a AP C3-convertase. This experiment was repeated twice. Lanes were run on the same gel but were noncontiguous (white lines). (B) $\mathrm{C}_{\mathrm{WT}}(1,000 \mathrm{RU})$ was immobilized via amine coupling to a CM5 Biacore chip. Convertase was formed by flowing fB $(2.6 \mu \mathrm{M})$ and $\mathrm{fD}(43 \mathrm{nM})$ in the presence of $\mathrm{Mg}^{2+}$. At the indicated time (arrows), C3 $3_{\mathrm{WT}}$ (gray line) or C $3_{923 \Delta \mathrm{DG}}$ (black line) was flowed over the surface. Remaining convertase was decayed using sDAF, and deposition of nascent C3b was measured. Resp. diff., response difference.

by the complement regulatory proteins $\mathrm{fH}, \mathrm{DAF}$, and MCP. The $C 3_{923 \triangle D G}$ mutation was found in heterozygosis in 2 DDD patients and in a relative in the early stages of the disease who present decreased levels of $\mathrm{C} 3$ and constitutive activation of the complement AP. C $3_{923 \Delta D G}$ causes the deletion of 2 amino acids within MG7, but this does not affect C3 expression or its overall structure. The mutant $\mathrm{C} 3_{923 \Delta \mathrm{DG}}$ protein was the predominant $\mathrm{C} 3$ protein in the plasma of $C 3_{923 \Delta D G}$ carriers, where it circulated in the form of native, nonactivated, $\mathrm{C} 3$. As a consequence of the mutation, the mutant $\mathrm{C} 3_{923 \Delta \mathrm{DG}}$ could not be activated to $\mathrm{C} 3 \mathrm{~b}$ by the $\mathrm{AP}$
C3-convertase. This explains why levels of C3 in the DDD patients carrying $\mathrm{C} 3_{923 \Delta \mathrm{DG}}$ were reduced only by $50 \%$, in contrast to the complete $\mathrm{C} 3$ consumption found in most DDD patients. Crucially, we demonstrate that the $\mathrm{C} 3_{923 \Delta \mathrm{DG}}$ mutant could be activated to $\mathrm{C}_{3} \mathrm{~b}_{923 \Delta \mathrm{DG}}$ by proteases, or to $\mathrm{C} 3\left(\mathrm{H}_{2} \mathrm{O}\right)_{923 \Delta \mathrm{DG}}$ by the spontaneous hydrolysis of the thioester, and both generated an active AP C3-convertase that cleaved WT C3 to generate C3b. Moreover, these mutant $\mathrm{C} 3$-convertases were resistant to inactivation by $\mathrm{fH}$, and neither $\mathrm{C}_{3} \mathrm{~b}_{923 \Delta \mathrm{DG}}$ nor $\mathrm{C} 3\left(\mathrm{H}_{2} \mathrm{O}\right)_{923 \Delta \mathrm{DG}}$ could be proteolyzed by $\mathrm{fI}$ in the presence of $\mathrm{fH}$.
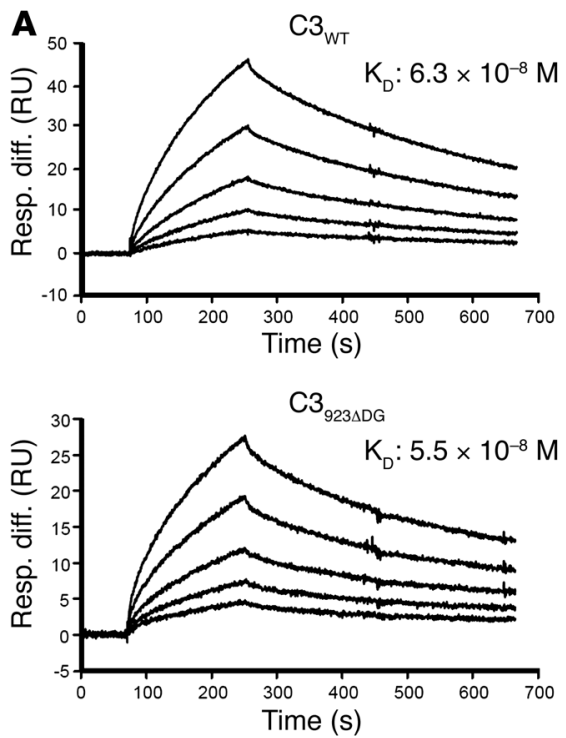

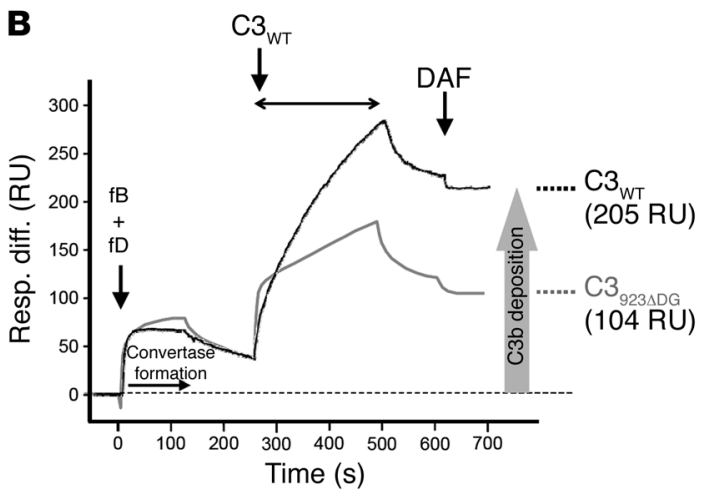

Figure 6

AP C3-convertase formation by $\mathrm{C}_{923 \Delta \mathrm{DG}}$ and C3WT. (A) Hydrolyzed C3 ${ }_{W T}(1,224 \mathrm{RU})$ or $\mathrm{C}_{923 \Delta \mathrm{DG}}(1,067 \mathrm{RU})$ was thiol-coupled to a CM5 Biacore chip. Convertase formation was analyzed by flowing $\mathrm{fB}(270$ to $17 \mathrm{nM})$ over the surface in the presence of $\mathrm{fD}(43 \mathrm{nM})$. Kinetics were analyzed according to the Langmuir 1:1 binding model. Convertase formation by mutant $\mathrm{C}_{923 \Delta \mathrm{DG}}$ and $\mathrm{C} 3\left(\mathrm{H}_{2} \mathrm{O}\right)_{W T}$, measured as $\mathrm{K}_{\mathrm{D}}$, was comparable. (B) $\mathrm{Hydrolyzed} \mathrm{C} 3_{W T}$ $(1,640 \mathrm{RU})$ or $\mathrm{C}_{923 \Delta \mathrm{DG}}(2,000 \mathrm{RU})$ was thiol-coupled to a CM5 Biacore chip. $\mathrm{fB}$ and fD were flowed over the surfaces to form either $\mathrm{C} 3\left(\mathrm{H}_{2} \mathrm{O}\right)_{\mathrm{WT}} \mathrm{Bb}$ (black line) or $\mathrm{C} 3\left(\mathrm{H}_{2} \mathrm{O}\right)_{923 \Delta \mathrm{DG}} \mathrm{Bb}$ (gray line). $\mathrm{C}_{\mathrm{WT}}$ was injected over the surface, where it was cleaved to nascent $\mathrm{C} 3 \mathrm{~b}$ and deposited on the surface via the thioester group. Remaining convertase after deposition was decayed using sDAF, and bound C3b was measured as change from baseline. 
A
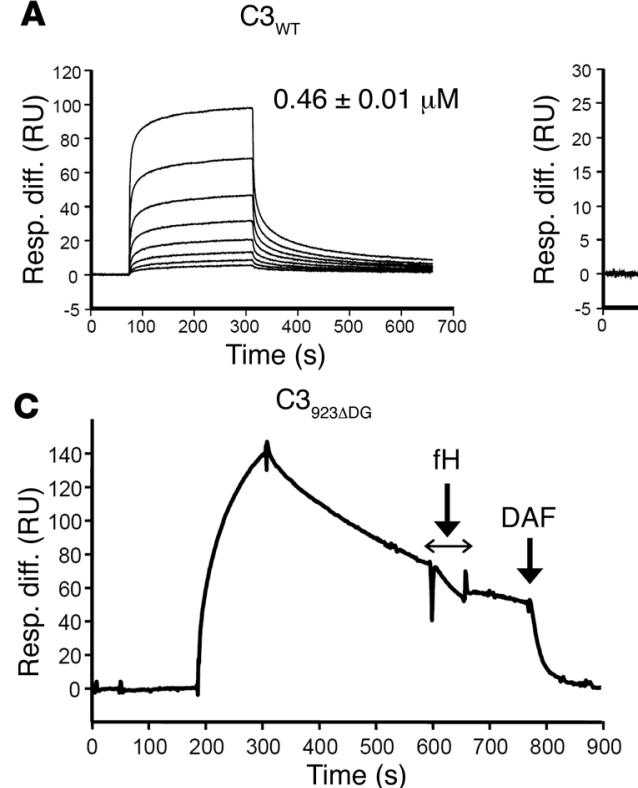

$\mathrm{C}_{923 \Delta \mathrm{DG}}$

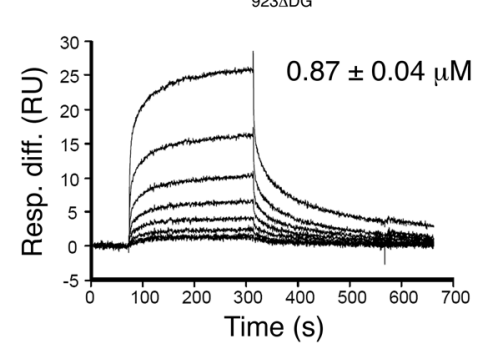

D

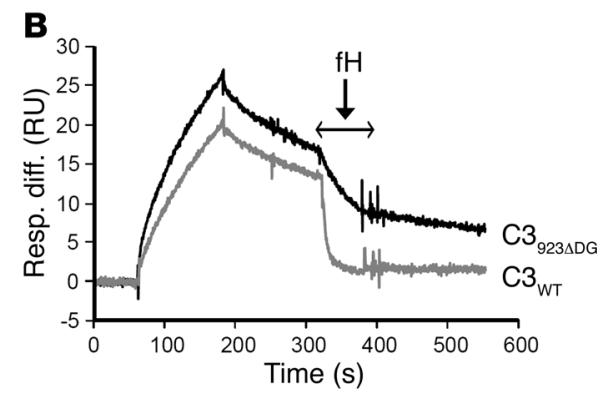

$\mathrm{C}_{923 \Delta \mathrm{DG}}$
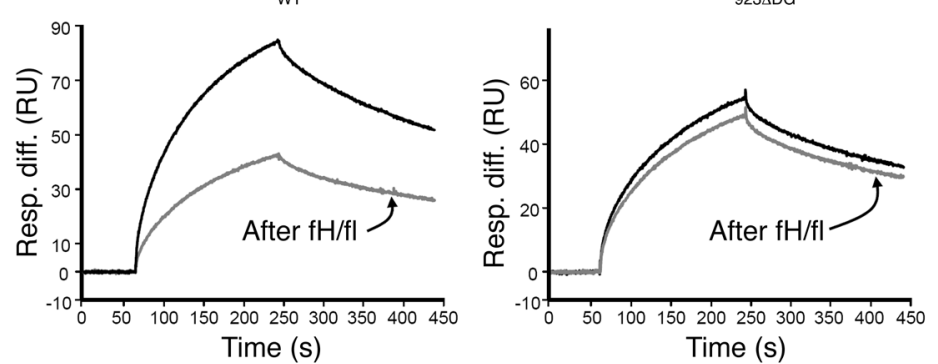

Figure 7

Reduced affinity of $\mathrm{fH}$ for hydrolyzed $\mathrm{C}_{923 \Delta \mathrm{DG}}$ impairs both decay of the mutant C3-convertase and fl-mediated inactivation of hydrolyzed $\mathrm{C}_{923 \Delta \mathrm{DG}}$. (A) Hydrolyzed C3 $\mathrm{WT}_{\mathrm{T}}(1,224 \mathrm{RU})$ or $\mathrm{C}_{923 \Delta \mathrm{DG}}(1,067 \mathrm{RU})$ were thiol-coupled to a CM5 Biacore chip. The affinity for native fH was analyzed by flowing $\mathrm{fH}\left(1 \mu \mathrm{M}\right.$ to $8 \mathrm{nM}$ ) over the surface and determined by steady-state analysis. The affinity of $\mathrm{fH}$ for $\mathrm{C} 3\left(\mathrm{H}_{2} \mathrm{O}\right)_{923 \Delta \mathrm{DG}}$ was reduced 2 -fold compared with $\mathrm{C}_{\text {wT }}$. Values are mean $\pm \mathrm{SD}$ of 3 determinations. (B) Convertase was formed on each hydrolyzed C3 surface by flowing $\mathrm{fB}$ and $\mathrm{fD}$. After a period of natural decay, $\mathrm{fH}(0.9 \mu \mathrm{M})$ was injected for 60 seconds. Convertase formed by $\mathrm{C}_{3}\left(\mathrm{H}_{2} \mathrm{O}\right)_{\mathrm{wT}}(\mathrm{gray}$ line $)$ was efficiently decayed by $\mathrm{fH}$, whereas the $\mathrm{C} 3\left(\mathrm{H}_{2} \mathrm{O}\right)_{923 \Delta \mathrm{DG}}$ convertase (black line) was inefficiently decayed. Binding $(\mathrm{RU})$ of $\mathrm{fH}$ to the surface in the absence of the convertase was subtracted; curves illustrate decay of $\mathrm{Bb}$. (C) In contrast, mutant convertase was efficiently decayed by DAF (0.4 $\mu \mathrm{M})$. (D) Hydrolyzed $\mathrm{C}_{\mathrm{WT}}$ or $\mathrm{C}_{923 \Delta \mathrm{DG}}$ was thiol-coupled to a CM5 Biacore chip. Initial formation of convertase on each surface was assessed by flowing fB and fD (black line). After complete decay of the convertase, $\mathrm{fH}(0.33 \mu \mathrm{M})$ and $\mathrm{fl}(0.11 \mu \mathrm{M})$ were flowed across the surface for $5 \mathrm{minutes}$ at $5 \mu \mathrm{l} / \mathrm{min}$. Convertase was then formed again (gray lines) using identical conditions. Enzyme formation by $\mathrm{C} 3\left(\mathrm{H}_{2} \mathrm{O}\right)_{\text {wT }}$ convertase was reduced $50 \%$ by $\mathrm{fl} / \mathrm{fH}$ treatment, whereas enzyme formation from $\mathrm{C} 3\left(\mathrm{H}_{2} \mathrm{O}\right)_{923 \Delta \mathrm{DG}}$ convertase was hardly affected.

These altered functions provide a pathogenic mechanism that explains the development of DDD in our patients. C $_{923}{ }_{9 \mathrm{DG}}$ circulates in the plasma of the patients at stable and high levels and constantly produces activated C3 molecules by the tick-over mechanism (or through non-complement-mediated proteolysis), which cannot be inactivated by $\mathrm{fH}$ in plasma. In turn, the activated mutant C3 molecules generate active AP C3-convertases that cannot be regulated by $\mathrm{fH}$, resulting in complement dysregulation in the fluid phase and substantial consumption of the WT C3 protein and $\mathrm{fB}$ in these heterozygote DDD patients.

In contrast to the situation in plasma, in which AP complement regulation depends almost exclusively on $\mathrm{fH}$, on cell surfaces, complement regulators like MCP and DAF efficiently regulate the generation and stability of the AP C3-convertase. Our demonstration that the AP C3-convertases generated from the mutant $\mathrm{C}_{923 \Delta \mathrm{DG}}$ were decayed normally by DAF, and that the activated molecules $\mathrm{C} 3 \mathrm{~b}_{923 \Delta \mathrm{DG}}$ and $\mathrm{C} 3\left(\mathrm{H}_{2} \mathrm{O}\right)_{923 \Delta \mathrm{DG}}$ were efficiently inactivated by fI in the presence of $\mathrm{MCP}$, is most relevant to DDD pathogenesis. Thus, not only is $\mathrm{C} 3_{923 \Delta \mathrm{DG}}$ resistant to cleavage to C3b by the AP C3-convertases, limiting the deposition of $\mathrm{C} 3_{923 \Delta \mathrm{DG}}$ on the cell surface to the very few molecules that may spontaneously activate in its vicinity, but also these few mutant molecules will be efficiently controlled by DAF and MCP on the cell membranes. These data provide conclusive evidence that DDD in our patients results exclusively from a fluid phaserestricted AP dysregulation.
$\mathrm{C} 3$ is the most abundant protein of the complement system $(\sim 1.3 \mathrm{mg} / \mathrm{ml})$. The structure of native $\mathrm{C} 3$ has been resolved at atomic resolution using X-ray crystallography (16) and reveals an intricate arrangement of 13 domains, including a core of 8 homologous macroglobulin domains forming a ring; a TED domain, linked to this ring by a CUB domain, that contains the reactive thioester; and the $\mathrm{C} 345 \mathrm{C}$ domain, which participates in the interaction with

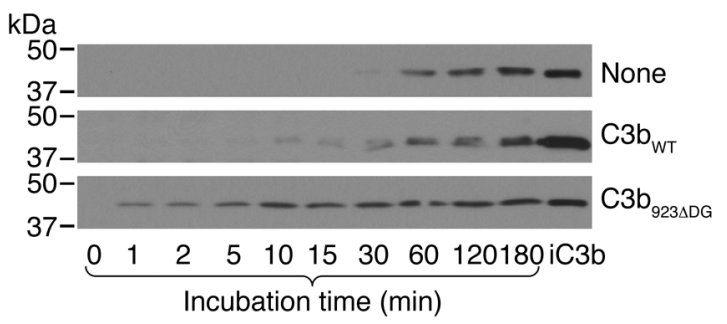

\section{Figure 8}

$\mathrm{C} \mathrm{b}_{923 \Delta \mathrm{DG}}$ activates $\mathrm{C} 3$ cleavage in normal human serum. The capacity of $C 3 b_{923 \triangle D G}$ and $C 3 b_{W T}$ to activate $C 3$ in normal serum was tested by incubating $180 \mathrm{ng}$ of each C3b with a 1:20 dilution of normal serum at $37^{\circ} \mathrm{C}$ in AP buffer ( $5 \mathrm{mM}$ Veronal; $150 \mathrm{mM} \mathrm{NaCl} ; 7 \mathrm{mM} \mathrm{MgCl} 2 ; 10 \mathrm{mM}$ EGTA, pH 7.4). Samples ( $5 \mu \mathrm{l})$ were taken at the indicated times and loaded into a 10\% SDS-PAGE. C3 activation was measured by the appearance of the $43-\mathrm{kDa}$ fragment of $\mathrm{C} 3 \alpha^{\prime}$ chain, as detected by Western blot. The $\alpha^{\prime} 43$ band of iC $3 b$ is shown for comparison. 


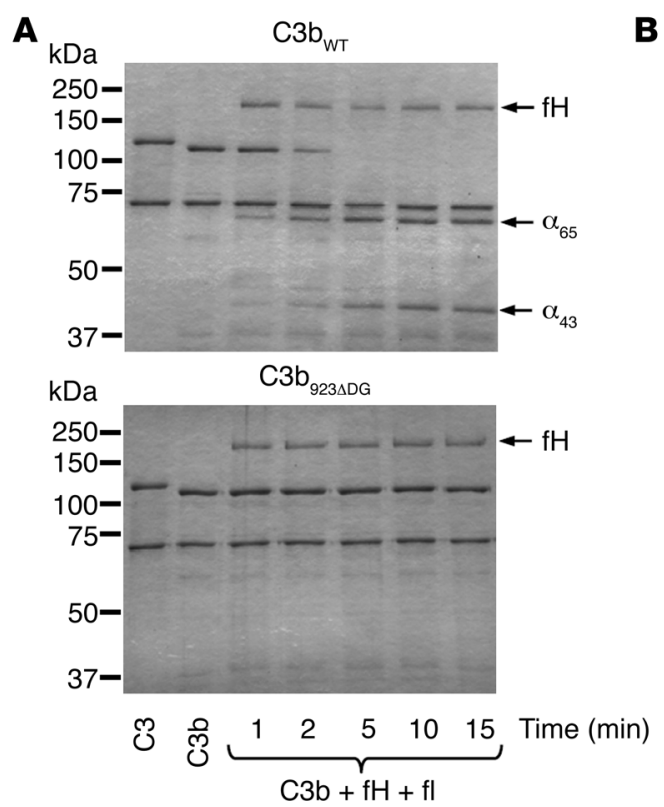

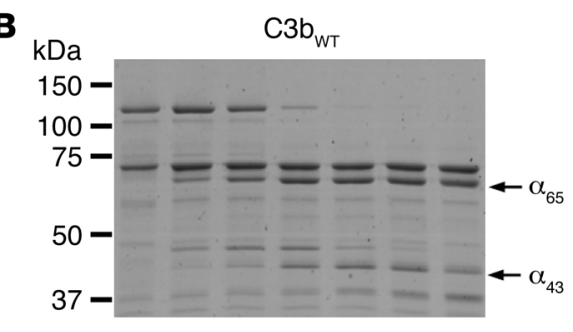

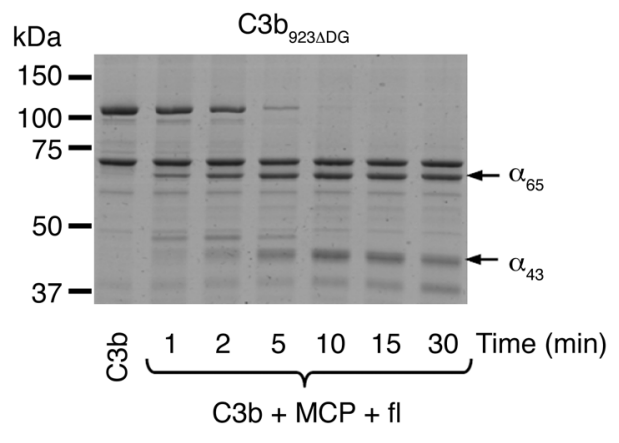

\section{Figure 9}

$\mathrm{C} \mathrm{b}_{923 \Delta \mathrm{DG}}$ is inactivated by $\mathrm{fl}$ and $\mathrm{MCP}$, but not by $\mathrm{fH}$ and fl. Activated $\mathrm{C} 3 \mathrm{~b}_{\text {WT }}$ or $\mathrm{C}_{3} \mathrm{~b}_{923 \Delta \mathrm{DG}}$ was incubated with $\mathrm{fl}$ and either $\mathrm{fH}(\mathbf{A})$ or SMCP (B). Cleavage of the $\alpha^{\prime}$ chain was indicated by generation of the $\alpha_{65}$ and $\alpha_{43}$ products. The experiment was repeated twice with identical results.
$\mathrm{fB}$. Cleavage of $\mathrm{C} 3$ into $\mathrm{C} 3 \mathrm{~b}$, or generation of $\mathrm{C} 3\left(\mathrm{H}_{2} \mathrm{O}\right)$, induces a huge conformational displacement of the TED domain, exposing the reactive group. In addition, this conformational change generates binding sites for a number of molecules, including the $\mathrm{AP}$ convertase component $\mathrm{fB}$ and the complement regulators $\mathrm{fH}$, DAF, and MCP (reviewed in ref. 17). Because the 2-amino acid deletion caused by the $3_{923 \Delta \mathrm{DG}}$ mutation lies within, and likely alters, these interaction surfaces (Supplemental Figure 5), we analyzed the interaction of $\mathrm{C}_{3} \mathrm{~b}_{923 \Delta \mathrm{DG}}$ and $\mathrm{C} 3\left(\mathrm{H}_{2} \mathrm{O}\right)_{923 \Delta \mathrm{DG}}$ with $\mathrm{fB}, \mathrm{fH}$, DAF, and MCP. Our data showed no differences in the assembly and stability of the AP C3-convertase formed by WT and mutant C3, which indicates that the mutation does not substantially modify the surfaces interacting with $\mathrm{fB}$. In contrast, the $\mathrm{C} 3_{923 \Delta \mathrm{DG}}$ mutant showed a differential sensitivity to regulation by $\mathrm{fH}, \mathrm{DAF}$, and MCP, clearly illustrating that there are distinct structural requirements underlying the decay regulatory activities of $\mathrm{fH}$ and DAF, as well as the fI cofactor activities of $\mathrm{fH}$ and MCP.

The crystal structure of the complex between $\mathrm{C} 3 \mathrm{~b}$ and a truncated form of $\mathrm{fH}$ has shown that the first 4 short consensus repeat domains (SCRs) of $\mathrm{fH}$, responsible for its decay-accelerating and fI cofactor activities, bind $\mathrm{C} 3 \mathrm{~b}$ in an extended configuration, which partially overlaps the site involved in the interaction with $\mathrm{fB}$ in the initial steps of the AP convertase assembly (Supplemental Figure 5 and refs. 18-20). These structural data explain previous mutagenesis experiments and functional analyses of disease-associated mutations indicating that $\mathrm{fH}$ competes with $\mathrm{fB}$ in the formation of the $\mathrm{C} 3 \mathrm{bB}$ proconvertase and interferes with the positioning of the $\mathrm{Bb}$ fragment, destabilizing $\mathrm{C} 3 \mathrm{bBb}$, the active $\mathrm{AP}$ C3-convertase. Our data support the hypothesis that the C $3_{923 \Delta \mathrm{DG}}$ mutation specifically alters the site of interaction of $\mathrm{fH}$ SCR1-SCR2 with C3b. Because the mutation does not affect the function of DAF,
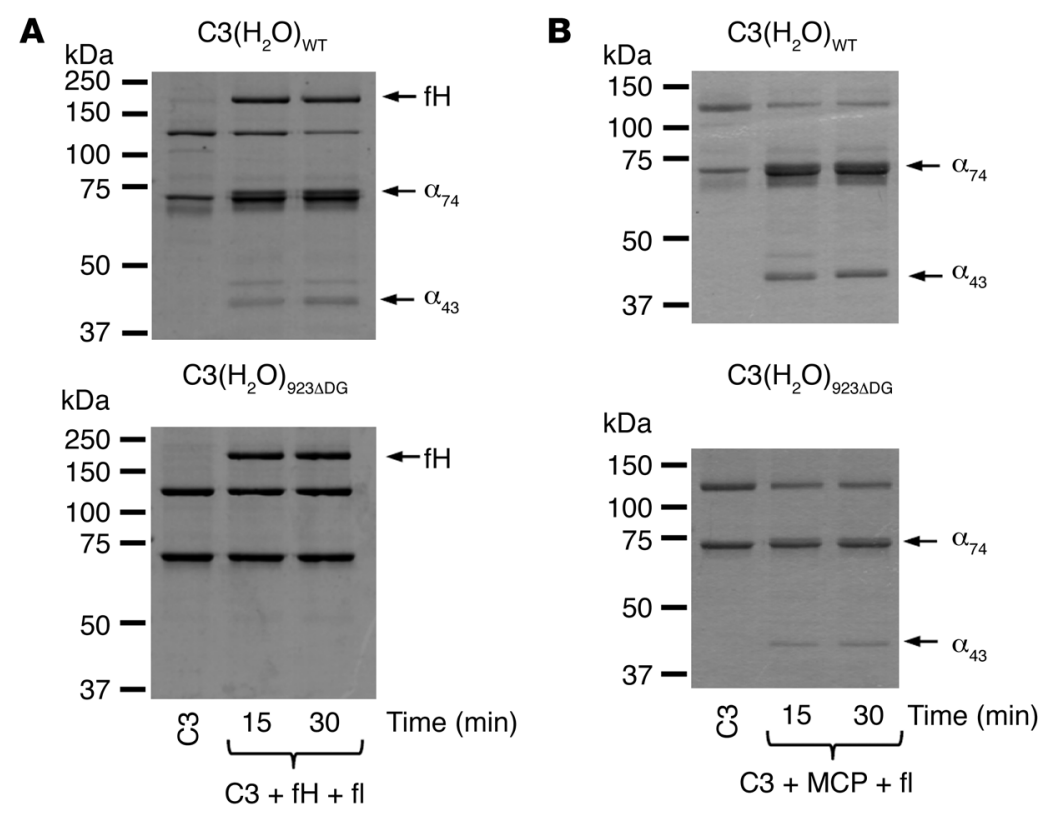

\section{Figure 10}

$\mathrm{C} 3\left(\mathrm{H}_{2} \mathrm{O}\right)_{923 \Delta \mathrm{DG}}$ is resistant to inactivation by $\mathrm{fl}$ in the presence of $\mathrm{fH}$, but not in the presence of SMCP. Hydrolyzed $\mathrm{C}_{923 \Delta \mathrm{DG}}$ or $\mathrm{C}_{\mathrm{WT}}$ were incubated with $\mathrm{fl}$ and either $\mathrm{fH}(\mathbf{A})$ or SMCP (B). Cleavage of the $\alpha^{\prime}$ chain was indicated by generation of the $\alpha_{74}$ and $\alpha_{43}$ products. The experiment was repeated twice. 
that $\mathrm{fH}$ and MCP have distinct structural requirements of $\mathrm{C} 3 \mathrm{~b}$ for their function. In agreement with early work $(21,22)$, our data indicate that the interaction between fH SCR1-SCR2 and $\mathrm{C} 3 \mathrm{~b}$ is critical for its cofactor activity, whereas for MCP, the interaction with this site in $\mathrm{C} 3 \mathrm{~b}$ does not substantially contribute to its cofactor activity $(23,24)$.

C $3_{923 \Delta \mathrm{DG}}$ could not be cleaved by the AP C3-convertase. Since the mutation locates distant to the AP C3-convertase cleavage site, one possibility is that it alters a region in $\mathrm{C} 3$ recognized by the substrate binding site in the $\mathrm{C} 3 \mathrm{~b}$ component of the AP C3-convertase. It was recently proposed that this interaction between $\mathrm{C} 3$ and $\mathrm{C} 3 \mathrm{~b}$ involves a large area on the same face of $\mathrm{C} 3$ (or C3b) that includes the domains MG3, MG4-5, and MG6-8 (25). Interestingly, this area of $\mathrm{C} 3$ overlaps with binding sites for the inhibitors compstatin (26), CRIg (27), and antibody S77 (28), which block substrate binding to the $\mathrm{C} 3$-convertase. In fact, the $\mathrm{C} 3_{923 \Delta \mathrm{DG}}$ mutation coincides with the interaction site of S77, which involves the His897 amino acid residue in C3 (28). It is therefore very likely that the mutant $\mathrm{C} 3_{923 \Delta \mathrm{DG}}$ could not be cleaved by the $\mathrm{C} 3 \mathrm{bBb}$ convertase because the sequence on $\mathrm{C} 3$ recognized by the highly specific substrate binding site located on the $\mathrm{C} 3 \mathrm{~b}$ component of the $\mathrm{C} 3 \mathrm{bBb}$ convertase has been lost (Supplemental Figure 6). These data may also explain why the AP C3-convertase generated by the mutant $\mathrm{C}_{3} \mathrm{~b}_{923 \Delta \mathrm{DG}}$ showed minimal activity compared with that generated by $\mathrm{C}_{\mathrm{WT}}$. In this context, however, it is remarkable that $\mathrm{C} 3\left(\mathrm{H}_{2} \mathrm{O}\right)_{923 \Delta \mathrm{DG}}$ built a relatively normal AP C3-convertase that efficiently cleaved $\mathrm{C} 3_{\mathrm{WT}}$ (Figure 6). This suggests that the structural requirements for the substrate $(\mathrm{C} 3)$ recognition in $\mathrm{C} 3 \mathrm{~b}$ are influenced by the presence of the $\mathrm{C} 3 \mathrm{a}$ domain in $\mathrm{C} 3\left(\mathrm{H}_{2} \mathrm{O}\right)$. This hypothesis, together with earlier data by Bexborn et al. (29) showing that the $\mathrm{C} 3\left(\mathrm{H}_{2} \mathrm{O}\right) \mathrm{Bb}$ convertase is more resistant to inactivation by $\mathrm{fH}$ and $\mathrm{fl}$, warrant further research - out of the scope of the present study - into the role and specific properties of the C3-convertase generated through the tick-over mechanism.

In conclusion, our identification and functional characterization of the C $3923 \Delta \mathrm{DG}$ mutation provided fundamental insights into both the pathogenic mechanisms underlying DDD and the structural aspects of substrate recognition and regulation of the $\mathrm{C} 3 \mathrm{bBb}$ convertase. Previous studies have shown that the control of complement activation is impaired in DDD patients and that dysregulation of the complement system may result from decreased activity of the complement regulatory protein $\mathrm{fH}$. We showed here that fluid phase complement dysregulation may also be a consequence of mutations in the AP C3-convertase components making the convertase resistant to inactivation by $\mathrm{fH}$. This has important therapeutic implications. Although replacement therapies providing $\mathrm{fH}$ may be successful in the former case, they will be ineffective if $\mathrm{C} 3$ is mutated. In this latter case, however, patients may benefit from therapies involving soluble forms of membraneassociated regulators like MCP. Recently, several mutations and polymorphisms in the genes encoding $\mathrm{fH}, \mathrm{MCP}$, and DAF have been associated with a number of disorders involving complement dysregulation (30). Interestingly, the functional characterization of these genetic variations and laboratory mutants reveals that, despite their common evolutionary origin and overlapping functions, $\mathrm{fH}, \mathrm{MCP}$, and DAF have distinct structural requirements in their regulatory activities. The structural characterization of the C3 $3_{923 \Delta \mathrm{DG}}$ mutant may help to delineate the interaction sites for the different complement regulators in $\mathrm{C} 3 \mathrm{~b}$, which, again, may have important implications in the design of therapeutic agents.

\section{Methods}

Patients. GN28 (II-2), a 53-year-old woman, presented with hypertension, microscopic hematuria and proteinuria at age 25 years, during the third trimester of her first and only identical twin pregnancy. She had an episode of nephritis at age 7. After 2 years of persistent microhematuria, proteinuria rising to $1.5 \mathrm{~g} /$ day and plasma creatinine $(\mathrm{Cr})$ of $0.9 \mathrm{mg} / \mathrm{dl}$, a renal biopsy was performed that illustrated segmental mesangial hypercellularity with thickened, brightly eosinophilic segments of basement membrane (Figure 1, A-D). There were prominent and diffuse C3 deposits, granular and nodular in some glomerular areas (Figure 1G). Transmission EM demonstrated the presence of a ribbon-like, osmiophilic deposit in the GBM (Figure 1, E and F). Mild deposits of C1q, IgA, and IgM were also present. Anti-nuclear (ANA) and anti-DNA antibodies were negative. Levels of $\mathrm{C} 4$ were normal, whereas $\mathrm{C} 3$ and $\mathrm{fB}$ were in the low-normal range. During the following 6 years, renal function progressively declined with proteinuria, reaching a nephrotic range of $7 \mathrm{~g} / \mathrm{d}$. In 1991, at age 35, the patient started dialysis. In 1992, she received a cadaver kidney allograft that lasted until 1997. Interestingly, beginning the second month after transplant, the patient presented with hypertension, microhematuria, and progressive proteinuria that reached nephrotic range in the fourth posttransplant year. The patient went back to dialysis the following year. In 1998, she received a second cadaver kidney allograft that lasted until 2003, following a similar period of progressive renal insufficiency and proteinuria, this time beginning 3 years after transplantation. Biopsies taken from this and the previous kidney allograft, illustrated microscopic findings similar to those found in the original kidney. In 2006, the patient received a third cadaver kidney allograft that is still functioning. However, the patient presents microhematuria, proteinuria, and progressive renal insufficiency that is accelerating in the third posttransplant year.

III-2, 26 years old, is one of the identical twin sons of GN28. At age 2, coincident with an episode of fever, he presented with microhematuria. In 1999 (age 16 years), he was admitted to hospital because of hyperurice$\mathrm{mia}(9.1 \mathrm{mg} / \mathrm{dl})$, showing proteinuria of $1.5 \mathrm{~g} / \mathrm{d}$, microhematuria (10-25 erythrocytes/field), and $\mathrm{Cr}$ of $1.4 \mathrm{mg} / \mathrm{dl}$, corresponding to a creatinine clearance (CCr) of $73 \mathrm{ml} / \mathrm{min}$. Like GN28, levels of C4 were normal, but $\mathrm{C} 3$ and $\mathrm{fB}$ were in the low-normal range. 5 years later (age 21 years), renal function started to decline with a Cr of $2 \mathrm{mg} / \mathrm{dl}$, CCr of $46 \mathrm{ml} / \mathrm{min}$, proteinuria of $1.1 \mathrm{mg} / \mathrm{dl}$, and persistent microhematuria. Another 6 months later, $\mathrm{Cr}$ and $\mathrm{CCr}$ rose to $3 \mathrm{mg} / \mathrm{dl}$ and $33 \mathrm{ml} / \mathrm{min}$, respectively. Renal biopsy at this time showed membranoproliferative glomerulonephritis with intense C3 deposits similar to those observed in the kidney biopsies of GN28. 9 years later, his renal function deteriorated to ESRD. The patient is currently on peritoneal dialysis.

III-1, 26 years old, is one of the identical twin sons of GN28. Despite microhematuria being evident in occasional follow-up visits, the patient was not available for assessment until 2006 (age 23 years). In his first visit to the nephrologist, he showed hyperuricemia of $8.5 \mathrm{mg} / \mathrm{dl}$, Cr of $1.4 \mathrm{mg} / \mathrm{dl}$ with a CCr of $105 \mathrm{ml} / \mathrm{min}$, proteinuria of $0.4 \mathrm{mg} / \mathrm{dl}$, and microhematuria (12 erythrocytes/field). These values were slightly increased in 2010 (Cr, $1.6 \mathrm{mg} / \mathrm{dl}$; CCr, $96 \mathrm{ml} / \mathrm{min}$; proteinuria of $0.5 \mathrm{mg} / \mathrm{dl}$ ), suggestive of progressive deterioration. As with the affected relatives, levels of $\mathrm{C} 4$ were normal, whereas $\mathrm{C} 3$ and $\mathrm{fB}$ were in the low-normal range. Renal biopsy showed membranoproliferative glomerulonephritis with intense mesangial C3 deposits and very limited C3 deposition within the GBM. This finding is in contrast with the kidney biopsies from GN28 and III-2, which may explain why the patient still preserves renal function.

The studies described herein received IRB approval (Comision de Bioetica, Consejo Superior de Investigaciones Científicas, Madrid, Spain). Patients and their relatives gave their informed consent. 
Complement analysis. Plasma or serum C3 and C4 levels were measured using standard nephelometric assays (Siemens). fH, fI, and fB levels were measured by sandwich ELISA as previously described (31-33). Anti-fH and C3Nef autoantibodies were detected as described previously $(34,35)$. Their concentrations in plasma were calculated by reference to the appropriate calibration curve prepared from purified proteins and expressed as $\mathrm{mg} / \mathrm{dl}$ plasma, or percent of control for fI concentration. $\mathrm{fB}$ hemolytic activity was tested according to Lesavre et al. (36).

Mutation screening and genotyping. Genomic DNA was obtained from peripheral blood mononuclear cells using Puregene Blood Core kit B (QIAGEN) according to the manufacturer's instructions. Each exon of the $C F H, M C P, C F I$, and $C F B$ genes was amplified from genomic DNA using specific primers derived from the $5^{\prime}$ and $3^{\prime}$ intronic sequences, as described previously (37-39). Exons of the $C 3$ gene were amplified from genomic DNA using the primers described in Supplemental Table 1. Automatic sequencing was performed in an $\mathrm{ABI} 3730$ sequencer using a dye terminator cycle sequencing kit (Applied Biosystems).

Biosensor analysis. To measure affinity of $\mathrm{fB}$ or $\mathrm{fH}$ for $\mathrm{C} 3$, hydrolyzed C $3_{\text {WT }}(1,224 \mathrm{RU})$ or $\mathrm{C} 3_{923 \Delta \mathrm{DG}}(1,067 \mathrm{RU})$ was thiol-coupled to a CM5 Biacore chip according to the manufacturer's instructions (ligand thiol coupling method; GE Healthcare). Convertase formation was analyzed by flowing $\mathrm{fB}(270 \mathrm{nM}$ to $17 \mathrm{nM})$ over the surface in the presence of $\mathrm{fD}$ $(1 \mu \mathrm{g} / \mathrm{ml}$; Comptech) in HBS/Mg/P (10 mM HEPES, pH 7.4; $150 \mathrm{mM}$ $\mathrm{NaCl} ; 1 \mathrm{mM} \mathrm{MgCl}$; and $0.005 \%$ surfactant-P20). The affinity for native $\mathrm{fH}$ was similarly analyzed by flowing $\mathrm{fH}(1 \mu \mathrm{M}$ to $8 \mathrm{nM})$ over the surface. All samples were injected using the Kinject command, flowed at $30 \mu \mathrm{l} / \mathrm{min}$, and analyzed at $25^{\circ} \mathrm{C}$. Kinetic experiments were carried out on a Biacore T100 (GE Healthcare); fB affinity was calculated according to the Langmuir 1:1 binding model, and $\mathrm{fH}$ affinity was determined by steady-state analysis (Biaevaluation v1.1).

In order to assess $\mathrm{fH}$-mediated decay of the convertases, hydrolyzed C $3_{\mathrm{WT}}$ or C3 ${ }_{923 \Delta \mathrm{DG}}$ was thiol-coupled to the chip, convertase was formed on each surface by flowing $\mathrm{fB}$ and $\mathrm{fD}$, and, after 60 seconds of natural decay, either native $\mathrm{fH}$ or $\mathrm{sDAF}$ was injected for 60 seconds. The same injection of $\mathrm{fH}$ was performed in the absence of convertase formation, and the binding curve was subtracted to control for $\mathrm{fH}$ binding to the surface; the resultant curve was therefore representative of Bb decay only. Accelerated decay was evident by the sharp increase in the dissociation rate.

Cofactor activity was assessed by flowing $\mathrm{fH}(0.33 \mu \mathrm{M})$ and $\mathrm{fI}(0.11 \mu \mathrm{M})$ across the surface for 5 minutes at $5 \mu \mathrm{l} / \mathrm{min}$. The capacity of $\mathrm{C} 3\left(\mathrm{H}_{2} \mathrm{O}\right)$ on the surface to form a convertase was assessed before and after $\mathrm{fH}$ and $\mathrm{fI}$ injection by flowing $\mathrm{fB}$ and $\mathrm{fD}$; decrease in convertase formation indicated cleavage of $\mathrm{C} 3\left(\mathrm{H}_{2} \mathrm{O}\right)$ to $\mathrm{iC} 3\left(\mathrm{H}_{2} \mathrm{O}\right)$.

To determine whether convertase formed by $\mathrm{C} 3\left(\mathrm{H}_{2} \mathrm{O}\right)_{923 \Delta \mathrm{DG}}$ was active and able to cleave $\mathrm{C} 33_{\mathrm{WT}}$ to $\mathrm{C} 3 \mathrm{~b}$, hydrolyzed $\mathrm{C} 3$ was thiol-coupled to a CM5 Biacore chip on a Biacore 3000 (GE Healthcare), and convertase was formed by flowing $\mathrm{fB}$ and $\mathrm{fD}$ in $\mathrm{HBS} / \mathrm{Mg} / \mathrm{P}$ for 120 seconds. After a short dissociation period (approximately 120 seconds), C $3_{\text {WT }}$ was flowed over the surface $(22 \mu \mathrm{M})$ for 240 seconds, Bb was decayed using sDAF, and C3b bound to the surface was assessed by the change in baseline as indicated. To determine whether $\mathrm{C} 3_{923 \Delta \mathrm{DG}}$ was a substrate for the C $3_{\mathrm{WT}}$ convertase, $\mathrm{C}^{3} \mathrm{~b}_{\mathrm{WT}}(1,000 \mathrm{RU})$ was coupled to the surface via the thioester as previously described (15). Convertase was formed in $\mathrm{HBS} / \mathrm{Mg} / \mathrm{P}$ by flowing $\mathrm{fB}(2.7 \mu \mathrm{M})$ and $\mathrm{fD}(43 \mathrm{nM})$ for 120 seconds. Following a period of dissociation, $\mathrm{C} 3_{923 \Delta \mathrm{DG}}$ was injected at a concentration of $0.4 \mu \mathrm{M}$ at $10 \mu \mathrm{l} / \mathrm{min}$ for 120 seconds. Remaining convertase was decayed using $0.4 \mu \mathrm{M}$ sDAF. The convertase was formed again as described above, and $0.4 \mu \mathrm{M} \mathrm{C} 3_{\mathrm{WT}}$ was similarly flowed over the surface. Cleavage and deposition of $\mathrm{C} 3 \mathrm{~b}$ was assessed by change in the baseline after regeneration.

Activation of $\mathrm{C} 3$ in fluid phase. Purified C3 $(2.7 \mu \mathrm{M}), \mathrm{fB}(0.5 \mu \mathrm{M})$, and $\mathrm{fD}$ $(0.17 \mu \mathrm{M})$ in $20 \mathrm{mM}$ sodium phosphate buffer ( $\mathrm{pH} 7), 40 \mathrm{mM} \mathrm{NaCl}$, and $2 \mathrm{mM}$ $\mathrm{MgCl}_{2}$ were incubated in a water bath at $37^{\circ} \mathrm{C}$. Aliquots of $5 \mu \mathrm{l}$ were extracted from the mix at $0,0.5,1,2,4,8$, and 16 minutes; mixed with SDS-PAGE sample buffer ( $2 \%$ SDS, $62.5 \mathrm{mM}$ Tris, $10 \%$ glycerol, and $0.75 \%$ bromophenol blue) to stop the reaction; and loaded into a $10 \%$ reducing SDS-PAGE gel. The gels were stained using Coomassie brilliant blue R-250 (BioRad).

$f H$ and $s M C P$ cofactor activity for fI-mediated proteolysis of fluid phase C3b. The fluid-phase cofactor activities of $\mathrm{fH}$ and sMCP were determined in a C3b proteolytic assay using purified proteins. In brief, $\mathrm{C} 3 \mathrm{~b}$, $\mathrm{fH}$ or $\mathrm{sMCP}$, and $\mathrm{fl}$ were mixed in $10 \mathrm{mM}$ HEPES ( $\mathrm{pH} 7.5$ ), $150 \mathrm{mM} \mathrm{NaCl}$, and $0.02 \%$ Tween 20. Final concentrations in one set were $1.9 \mu \mathrm{M} \mathrm{C} 3 \mathrm{~b}, 0.2 \mu \mathrm{M} \mathrm{fI}$, and $0.46 \mu \mathrm{M}$ sMCP, and in the other set $0.42 \mu \mathrm{M} \mathrm{C} 3 \mathrm{~b}, 43 \mathrm{nM}$ fl, and $47 \mathrm{nM} \mathrm{fH}$. Molarities were calculated using the following masses: fI, $88 \mathrm{kDa}$; C3, $185 \mathrm{kDa}$; fH, 155 kDa; fD, 23 kDa; fB, 93 kDa; sDAF, 28 kDa; sMCP, 28 kDa. Mixtures were incubated at $37^{\circ} \mathrm{C}$ in a water bath, and $6-\mu \mathrm{l}$ aliquots were collected at $0,1,2,5,10,15,30$, and 60 minutes. The reaction was stopped by the addition of $5 \mu \mathrm{l}$ SDS sample buffer. Samples were analyzed in $10 \%$ SDS-PAGE under reducing conditions. Gels were stained with Coomassie brilliant blue R-250 (BioRad), and proteolysis of C3b was determined by analyzing the cleavage of the $\alpha^{\prime}$ chain.

\section{Acknowledgments}

We are grateful to the patients and their relatives for their participation in this study. We thank Vivian de los Rios (Proteomics and Genomics Facility, CIB), the members of Secugen S.L., and the DNA sequencing laboratory at CIB for invaluable technical assistance with patient sequencing and genotyping. We thank Svetlana Hakobyan (Cardiff University) for measuring TCC in plasma samples and Susan Lea (University of Oxford, Oxford, United Kingdom) for gifts of sDAF and sMCP. This work was funded by the Spanish Ministerio de Educación y Cultura (grants SAF2008-00226, SAF2008-00451, and SAF2006-02948), the Ciber de Enfermedades Raras (INTRA/08/738.2), the Red Temática de Investigación Cooperativa en Cáncer (RD06/0020/1001), the Fundación Renal Iñigo Alvarez de Toledo, the Fundación Areces, the Human Frontiers Science Program (RGP39/2008), and MRC UK project grant 84908.

Received for publication April 14, 2010, and accepted in revised form July 21, 2010.

Address correspondence to: Santiago Rodríguez de Córdoba, Centro de Investigaciones Biológicas, Ramiro de Maeztu 9, 28040 Madrid, Spain. Phone: 34.918373112; Fax: 34.915360432; E-mail: SRdeCordoba@cib.csic.es.
1. Amara $U$, et al. Interaction between the coagulation and complement system. Adv Exp Med Biol. 2008;632:71-79.

2. Lachmann PJ. The amplification loop of the complement pathways. Adv Immunol. 2009;104:115-149.

3. Walport MJ. Complement- second of two parts. NEngl J Med. 2001;344(15):1140-1144.

4. Walport MJ. Complement- first of two parts. NEngl JMed. 2001;344(14):1058-1066.
5. Smith RJH, et al. New approaches to the treatment of dense deposit disease. J Am Soc Nephrol. 2007;18(9):2447-2456.

6. Walker PD. Dense deposit disease: new insights. Curr Opin Nephrol Hypertens. 2007;16(3):204-212.

7. Ault $\mathrm{BH}$, et al. Human factor $\mathrm{H}$ deficiency. J Biol Chem. 1997;272(40):25168-25175.

8. Dragon-Durey MA, et al. Heterozygous and homozygous factor $h$ deficiencies associated with hemo- lytic uremic syndrome or membranoproliferative glomerulonephritis: report and genetic analysis of 16 cases. J Am Soc Nephrol. 2004;15(3):787-795.

9. Zipfel PF, Heinen S, Józsi M, Skerka C. Complement and diseases: Defective alternative pathway control results in kidney and eye diseases. $\mathrm{Mol}$ Immunol. 2006;43(1-2):97-106.

10. Licht C, et al. Deletion of Lys 224 in regulatory domain 4 of Factor $\mathrm{H}$ reveals a novel pathomechanism 
for dense deposit disease (MPGN II). Kidney Int. 2006;70(1):42-50.

11. HøgÅsen K, Jansen JH, Mollnes TE, Hovdenes J, Harboe M. Hereditary porcine membranoproliferative glomerulonephritis type II is caused by factor H deficiency. J Clin Invest. 1995;95(3):1054-1061.

12. Pickering MC, et al. Uncontrolled C3 activation causes membranoproliferative glomerulonephritis in mice deficient in complement factor $\mathrm{H}$. Nat Genet. 2002;31(4):424-428.

13. Rose KL. Factor I is required for the development of membranoproliferative glomerulonephritis in factor H-deficient mice. J Clin Invest. 2008;118(2):608-618.

14. Pickering MC, et al. Prevention of C5 activation ameliorates spontaneous and experimental glomerulonephritis in factor H-deficient mice. Proc Natl Acad Sci U S A. 2006;103(25):9649-9654.

15. Harris CL, Abbott RJM, Smith RA, Morgan BP, Lea SM. Molecular dissection of interactions between components of the alternative pathway of complement and decay accelerating factor (CD55). J Biol Chem. 2005;280(4):2569-2578.

16. Janssen BJC, et al. Structures of complement component $\mathrm{C} 3$ provide insights into the function and evolution of immunity. Nature. 2005 437(7058):505-511.

17. Gros P, Milder FJ, Janssen BJC. Complement driven by conformational changes. Nat Rev Immunol. 2008; $8(1): 48-58$

18. Torreira E, Tortajada A, Montes T, Rodríguez de Córdoba S, Llorca O. 3D structure of the $\mathrm{C} 3 \mathrm{bB}$ complex provides insights into the activation and regulation of the complement alternative pathway convertase. Proc Natl Acad Sci U S A. 2009;106(3):882-887.

19. Torreira E, Tortajada A, Montes T, Rodriguez de Cordoba S, Llorca O. Coexistence of closed and open conformations of complement factor $b$ in the alternative pathway $\mathrm{C} 3 \mathrm{bB}(\mathrm{Mg} 2+)$ proconvertase. J Immunol. 2009;183(11):7347-7351.

20. Wu J, Wu YQ, Ricklin D, Janssen BJC, Lambris JD, Gros P. Structure of complement fragment
C3b-factor $\mathrm{H}$ and implications for host protection by complement regulators. Nat Immunol. 2009;10(7):728-733.

21. Gordon DL, Kaufman RM, Blackmore TK, Kwong J, Lublin DM. Identification of complement regulatory domains in human factor H. J Immunol. 1995 155(1):348-356.

22. Kuhn S, Skerka C, Zipfel PF. Mapping of the complement regulatory domains in the human factor $\mathrm{H}$-like protein 1 and in factor H1. J Immunol. 1995; 155(12):5663-5670.

23. Liszewski MK, Leung MK, Schraml B, Goodship THJ, Atkinson JP. Modeling how CD46 deficiency predisposes to atypical hemolytic uremic syndrome. Mol Immunol. 2007;44(7):1559-1568.

24. Richards A, et al. Implications of the initial mutations in membrane cofactor protein (MCP; CD46) leading to atypical hemolytic uremic syndrome. Mol Immunol. 2007;44(1-3):111-122.

25 . Rooijakkers SHM, et al. Structural and functiona implications of the alternative complement pathway C3 convertase stabilized by a staphylococcal inhibitor. Nat Immunol. 2009;10(7):721-727.

26. Janssen BJC, Halff EF, Lambris JD, Gros P. Structure of compstatin in complex with complement component $\mathrm{C} 3 \mathrm{c}$ reveals a new mechanism of complement inhibition. J Biol Chem. 2007;282(40):29241-29247.

27. Wiesmann C, et al. Structure of C3b in complex with CRIg gives insights into regulation of complement activation. Nature. 2006;444(7116):217-220.

28. Katschke KJ, et al. Structural and functional analysis of a C3b-specific antibody that selectively inhibits the alternative pathway of complement. J Biol Chem. 2009;284(16):10473-10479.

29. Bexborn F, Andersson PO, Chen H, Nilsson B, Ekdahl KN. The tick-over theory revisited: Formation and regulation of the soluble alternative complement $\mathrm{C} 3$ convertase $(\mathrm{C} 3(\mathrm{H} 2 \mathrm{O}) \mathrm{Bb})$. Mol Immunol. 2008;45(8):2370-2379.

30. Rodriguez de Cordoba S, Goicoechea de Jorge E. Translational mini-review series on complement factor $\mathrm{H}$ : genetics and disease associations of human complement factor H. Clin Exp Immunol. 2008; 151(1):1-13.

31. Goicoechea de Jorge E, et al. Gain-of-function mutations in complement factor B are associated with atypical hemolytic uremic syndrome. Proc Natl Acad Sci U S A. 2007;104(1):240-245.

32. Gonzalez-Rubio C, Ferreira-Cerdan A, Ponce IM, Arpa J, Fontan G, Lopez-Trascasa M. Complement Factor I deficiency associated with recurrent meningitis coinciding with menstruation. Arch Neurol. 2001;58(11):1923-1928.

33. Hakobyan S, et al. Measurement of factor $\mathrm{H}$ variants in plasma using variant-specific monoclonal antibodies: application to assessing risk of agerelated macular degeneration. Invest Ophthalmol Vis Sci. 2008;49(5):1983-1990.

34. Abarrategui-Garrido C, Martinez-Barricarte R, Lopez-Trascasa M, Rodriguez de Cordoba S, Sanchez-Corral P. Characterization of complement factor $\mathrm{H}$-related (CFHR) proteins in plasma reveals novel genetic variations of CFHR1 associated with atypical hemolytic uremic syndrome. Blood. 2009;114(19):4261-4271.

35. Rother U. A new screening test for $\mathrm{C} 3$ nephritis factor based on a stable cell bound convertase on sheep erythrocytes. J Immunol Methods. 1982;51(1):101-107.

36. Lesavre PH, Hugli TE, Esser AF, Müller-Eberhard HJ. The alternative pathway C3/C5 convertase: chemical basis of factor B activation. J Immunol. 1979;123(2):529-534.

37. Fremeaux-Bacchi V, et al. Complement factor I: a susceptibility gene for atypical haemolytic uraemic syndrome. J Med Genet. 2004;41(6):e84.

38. Perez-Caballero D, et al. Clustering of missense mutations in the $\mathrm{C}$-terminal region of factor $\mathrm{H}$ in atypical hemolytic uremic syndrome. Am J Hum Genet. 2001;68(2):478-484.

39. Richards A, et al. Mutations in human complement regulator, membrane cofactor protein (CD46), predispose to development of familial hemolytic uremic syndrome. Proc Natl Acad Sci U S A. 2003. 100(22):12966-12971. 